\title{
The mammalian embryo's first agenda: making trophectoderm
}

\author{
ESZTER POSFAI*,1, ISIDORA ROVIC and ANDREA JURISICOVA*,2 \\ ${ }^{1}$ The Hospital for Sick Children, Program in Developmental and Stem Cell Biology, Peter Gilgan Centre for Research \\ and Learning and ${ }^{2}$ Lunenfeld Tanenbaum Research Institute, Sinai Health System and Departments of Obstetrics \& \\ Gynecology and Physiology, University of Toronto, Toronto, ON, Canada
}

\begin{abstract}
One of the bottlenecks for a successful pregnancy in mammalian species is the implantation of the early embryo into the wall of the mother's uterus. The first cell lineage the embryo sets aside following fertilization is the trophectoderm - a specialized cell type that establishes contact with the mother and mediates embryo implantation. We summarize the events that lead to the formation of the trophectoderm lineage in the preimplantation embryo and highlight key features of this cell type, which could be useful in the clinical setting for prediction of implantation outcomes.
\end{abstract}

KEY WORDS: preimplantation embryo, trophectoderm, inner cell mass, implantation

\section{Introduction}

During the first few days of mammalian development ( $\sim 4$ days in mouse and $\sim 7$ days in human) the embryo is freely floating along the oviduct until it arrives at its site of implantation in the uterus. The embryo is provided with sufficient nutrients to propel through this phase of development. Mammalian eggs do not have yolk stores, like other non-mammalian species, and in order to thrive need to establish physical contact with the mother to ensure continued nutrient flow. Therefore preimplantation development is dedicated to setting aside so-called extraembryonic cells within the embryo, which function to establish maternal contact and nurture the developing fetus in the uterus.

The very first cell fate decision in the embryo produces two cell types: the trophectoderm (TE) and the inner cell mass (ICM), creating a structure called the blastocyst. The TE will form as an epithelial layer of cells on the surface of the embryo, engulfing a fluid filled blastocoel cavity and a group of internal cells - the ICM. ICM cells will give rise to the embryo proper, as well as additional extraembryonic membranes, while TE cells are the precursors of most of the future embryonic portion of the placenta. The placenta is a peculiar organ - absolutely essential for fetal survival, but with an expiry date much shorter than the lifespan of the organism. As such, it is also more permissive towards accumulating genetic mutations compared to the embryo itself (Greco, Minasi \& Fiorentino, 2015, Munne et al., 2017, Spinella et al., 2017).
Here we review the events that lead to the formation of the TE in the preimplantation embryo and the key properties of this tissue, which facilitate implantation. We compare, where possible, mouse and human.

\section{Trophectoderm development in mouse}

\section{Compaction and intracellular symmetry breaking by polarization}

The first three cleavage divisions in the early preimplantation embryo produce loosely associated, morphologically indistinguishable, totipotent blastomeres, which have the potential to give rise to any cell type (Fig. 1). Two concomitant events take place at the 8-cell stage: polarization and compaction, both of which serve as the basis for blastocyst formation (Fig. 2). Each blastomere becomes polarized along the apical-basal axis, which involves uneven distribution of both cell surface proteins and cytoskeletal components between apical and basolateral domains (Fleming \& Johnson, 1988; Johnson \& Maro, 1985). Compaction describes the process during which loosely associated cells increase cellcell contacts, flatten their surfaces and condense into a sphere.

The first intracellular rearrangements involve the apical localization of myosin (Sobel, 1983; Zhu, Leung, Shahbazi, \&

Abbreviations used in this paper: $\mathrm{AD}$, apical domain; AJ, adherens junction; ICM, inner cell mass; TE, trophectoderm; TS, trophoblast stem cell.

\footnotetext{
*Address correspondence to: Eszter Posfai. Currently at: Princeton University. Department of Molecular Biology, LewisThomas Lab 234, Washington Road, Princeton, NJ 08544, USA E-mail: eszterposfai@ gmail.com - iD https://orcid.org/0000-0002-4871-6652 - or Andrea Jurisicova. LunenfeldTanenbaum Research Institute, Sinai Health System and Departments of Obstetrics \& Gynecology and Physiology, University ofToronto, 60 Murray St, Suite 6-1016-1, Toronto, ON M5T 3L9, Canada. Tel: 416-586-4800 x 2052. Fax: 416-586-5993. E-mail: jurisicova@lunenfeld.ca - (iD) https://orcid.org/0000-0003-2166-4298
} 


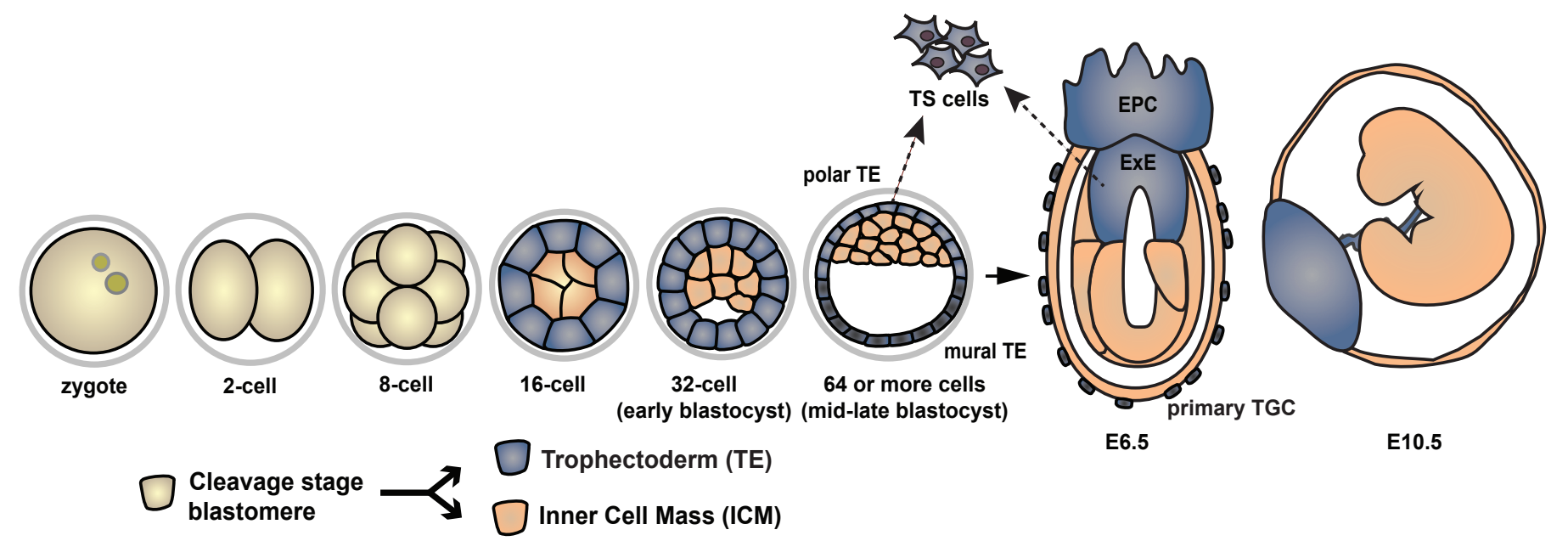

Fig. 1. Overview of early mouse development. Early divisions of the fertilized egg produce cleavage stage blastomeres, which have unlimited developmental potential. Starting at the 16-cell stage, cells gradually start to differentiate to form two lineages: the trophectoderm (TE), which will give rise to the foetal portion of the placenta and the inner cell mass (ICM), which will give rise to the embryo proper and other extra-embryonic membranes. By the end of preimplantation development the blastocyst is formed with the TE organised into a surface epithelial layer, engulfing the ICM and a fluid filled blastocoel cavity. Two TE subpopulations can also be distinguished by the mid-late blastocyst stage: the polar TE, which is in contact with the ICM and the mural TE around the blastocoel cavity. The late blastocyst implants into the uterine wall. The mural TE gives rise to primary trophoblast giant cells (TGCS), while the polar TE rapidly proliferates to form the ectoplacental cone (EPC) and the extra-embryonic ectoderm (ExE) by embryonic day (E) 6.5. The polar TE and the EXE are the source for trophoblast stem (TS) cells.

Zernicka-Goetz, 2017) where it assembles with the subcortical actin cytoskeleton. This is followed by apical localization of a number of other components, which build an apical domain (AD) at the center of the exposed surface of each cell. The AD consists of atypical protein kinase C (aPKC) isoforms, Par proteins, activated Ezrin-Radixin-Moesin (ERM) and microvilli (Ajduk \& Zernicka-Goetz, 2016). Finally the underlying actomyosin network is excluded from the region of the mature $A D$ and forms a ring around it (Zhu et al., 2017).

The major components of basolateral cell-cell contacts that form during the 8-cell stage are adherens junctions (AJs). AJs are composed of transmembrane E-cadherin molecules, which link neighboring cells together in a $\mathrm{Ca}^{2+}$-dependent manner and intracellular alpha and beta catenins, which engage cortical actin filaments. Embryo compaction requires AJs, as lack of E-cadherin or Beta-catenin leave blastomeres loosely associated (De Vries et al., 2004; Stephenson, Yamanaka, \& Rossant, 2010). Maître et al., showed that AJs likely act as passive anchoring points between neighboring blastomeres and pulsing contractions generated by the apical actomyosin cortex are the main force generators that drive compaction (Maître et al., 2012). Additionally, and not excluding the previous model, E-cadherin- and actomyosincontaining contractile filopodia, emerge from the regions where cell-cell contacts meet the embryo surface and extend to contact the apical surface of neighboring cells (Fig. 2). These filopodia are only present during compaction and have been proposed to play a role in pulling cells together (Fierro-González, White, Silva, \& Plachta, 2013).

AD formation can proceed without cell-cell contact, however, contact was shown to be required for the proper localization of the AD (Johnson \& Ziomek, 1981a; Stephenson et al., 2010; Vinot et al., 2005). Interestingly, it did not require E-cadherin specifically, as contact with a simple bead was sufficient to induce AD formation on the opposite pole of a blastomere, even if the blastomere itself lacked E-cadherin (Korotkevich et al., 2017). These observations raise the possibility that a purely mechanical stimulus, perhaps through cell shape change may orient AD formation. Subcortical myosin localization was shown to be a prerequisite for AD formation (Zhu et al., 2017) and cell-cell contacts regulate myosin localization by directing myosin towards the center of the apical cortex (Maître et al., 2015; Sobel, 1983). Therefore, while AD formation and subcortical myosin accumulation can occur without cell-cell interaction, contact likely orients and concentrates these components at the center of the contact-free surface.

What are the signaling pathways that regulate these morphogenetic events? Apical myosin polarization depends on Phospholipase C (PLC)-mediated Protein kinase C (PKC) activation (Ohsugi, Ohsawa, \& Yamamura, 1993; Winkel, Ferguson, Takeichi, \& Nuccitelli, 1990; Zhu et al., 2017). The small Rho GTPases RhoA and Cdc42 were needed for the polarization of cytoskeletal actin (Clayton, 1999) and RhoA for polarization of myosin (Zhu et al., 2017). How any of these activities link to contact-induced asymmetries remains an open question.

Chemical activation of PKC or expressing active forms of RhoA or Cdc42 in 4-cell blastomeres can induce premature actomyosin polarization and compaction, but not polarization of AD components (Clayton, 1999; Zhu et al., 2017). Thus, all components required for establishment of a contractile actomyosin cortex needed for compaction are present already at the 4-cell stage, however AD formation needs additional factors or signaling cues downstream of polarized actomyosin. A candidate downstream signaling factor may be the Rho-associated kinase (ROCK), as ROCK inhibition does not influence compaction but affects $A D$ formation (Kono, Tamashiro, \& Alarcon, 2014). Moreover, ROCK is known to phosphorylate and activate ERM proteins, which are required for organizing the apical cortex (Amano, Nakayama, \& Kaibuchi, 2010). Further studies are needed to clarify the roles of ROCK in this context. Despite accumulating knowledge on the 
sequence of signaling events leading to polarization and compaction the important question of what triggers these activities during development remains unanswered.

\section{Intercellular symmetry breaking - divisions produce different cell types}

Polarized 8-cell blastomeres divide with different orientations with respect to the $A D$ and the axis of the embryo, producing for the first time morphologically distinct cells at the 16-cell stage. The orientation of cell divisions will influence two properties of daughter cells: whether they inherit any of the AD (resulting in polar and apolar cells) and their position in the embryo (inside cells sequestered in the core and outside cells that bear an exposed surface). What determines cleavage angle and thereby the proportions of different cell types in the embryo?

An early study found that division planes were oriented randomly with respect to the axis of cell polarity (Pickering, Maro, Johnson, \& Skepper, 1988). However it noted a correlation between the size of the $A D$ and daughter cell polarity - a larger AD was more likely to be cleaved in a randomly oriented division and thus yielded two polarized progeny. Live imaging of spindle formation reveled no tight control over spindle orientation, however the shape of cells during mitosis did to some extent have an effect (Dard, Louvet-Vallée, \& Maro, 2009). Cells round up during mitosis and some bulge out of the embryo more than others. These bulging cells showed a tendency for aligning their spindles with the apical-basal axis of the cell, resulting in a polar and an apolar progeny. A more recent study observed a similar spindle-orientation phenomenon - the mitotic spindle was often aligned with the apical-basal axis, perpendicular to the AD (Korotkevich et al., 2017). Interestingly, orientation was random in embryos lacking an $A D$. They also observed that as the AD forms, it recruits microtubule organizing centers (MTOCs) to the subapical regions of blastomeres. This suggests that the $A D$ influences the plane of division, although it is still unclear how exactly the AD would orient the spindle. Interestingly, this would imply that the AD itself ensures its own distribution in daughter cells, favoring a pattern where one cell inherits the AD, while the other does not.

The 8-to-16-cell divisions produce three types of cells: inside cells, which are always apolar, and outside cells, which can either remain polarized or become apolar. This later population is though to arise from divisions where the exposed surface, but not the AD is cut by the cleavage furrow (Fig. 3). Regardless of whether the cleavage plane is controlled or random, there is a degree of variability reported from embryo-to-embryo both in terms of inside/outside and polar/apolar cell numbers. On average, a freshly formed 16cell stage embryo has 1-2 apolar inside, 10 polar outside and 4-5 apolar outside cells (Anani, Bhat, Honma-Yamanaka, Krawchuk, \& Yamanaka, 2014; Dietrich \& Hiiragi, 2007; Fujimori, Kurotaki, Komatsu, \& Nabeshima, 2009).

Of note, the recent study by Zenker et al., is ruffling some feathers by reporting that the AD may in fact disassemble prior to the 8-to-16-cell divisions and reassemble de novo at the 16-cell stage (Zenker et al., 2018). However, since the AD does not appear on all outside cells at the 16-cell stage and the frequency of asymmetric divisions are reflected in the number of apolar/polar progeny (Anani et al., 2014), it is likely that some component of it is inherited in a membrane-bound form through divisions. Other members may indeed disassemble before division and then use the

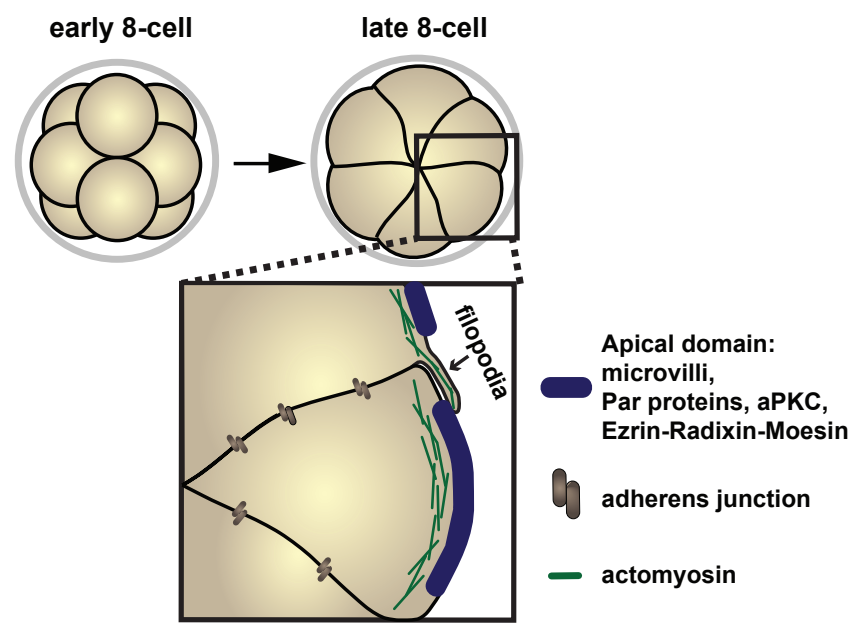

Fig. 2. Polarization and compaction. At the 8-cell stage each blasomere becomes polarized along the apical-basal axis, forms an apical domain at the center of its exposed surface and a subcortical actomyosin network. Blastomeres also increase cell-cell contact by flattening their surfaces against one another and forming adherens junctions between them. The forces driving compaction are generated by the subcortical actomyosin network and by the pulling forces from filopodia extending from some cells and contacting neighbours.

membrane-bound component as a seeding cue to re-establish the $A D$. Live imaging of endogenously tagged AD members is needed to resolve this issue in the future.

\section{Dynamic sorting at the morula stage}

How does an embryo acquire an outside layer of TE cells and an inside population of ICM cells with an approximate 2 to 1 ratio, as observed by the early-mid blastocyst stage (Suwińska, Czołowska, Ożdżeński \& Tarkowski, 2008)? Which property - position or polarity - matter for future cell fate? Models half a century old have been proposed supporting both position (Tarkowski \& Wróblewska, 1967) and polarity-driven events (Johnson \& Ziomek, 1981b; 1981a). Using advanced imaging techniques, it is now clear that dynamic division-independent cell rearrangements occur during the 16-cell stage: while outside polar and inside apolar cells remain in place, most of the apolar outside cells internalize and contribute to the inner compartment (Fig. 3) (Anani et al., 2014; Korotkevich et al., 2017; Maître et al., 2016; Samarage et al., 2015).

What are the mechanisms that regulate these dynamic cell rearrangements? An isolated polar/apolar cell couplet from a 16-cell stage embryo mimics this internalization event - the polar cell envelopes the apolar neighbor. Measuring the curvatures of the cell membranes at cell-cell contacts on such isolated couplets revealed that apolar cells had higher cortical tension than polar cells (Anani et al., 2014). Direct measurement of surface tensions using micropipette aspiration confirmed the asymmetry between apolar and polar blastomeres and a mathematical model was used to predict that cell internalization would take place if the tension asymmetry exceeded 1.5-fold (Maître et al., 2016). The increased cortical tension of apolar cells was generated by subcortical contractile actomyosin. Phosphorylated myosin light chain II, a marker of activated myosin was enriched at the cortex of apolar cells and inhibiting contractility genetically or using an inhibitor resulted in failure to internalize (Anani et al., 2014; Maître et al., 2016; Sa- 


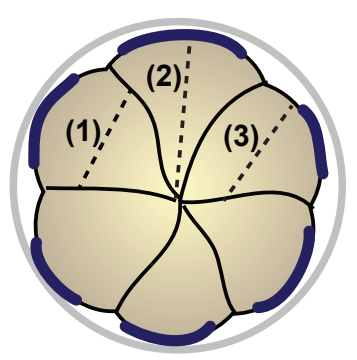

late 8-cell

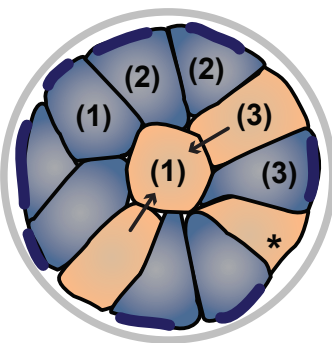

early 16-cell

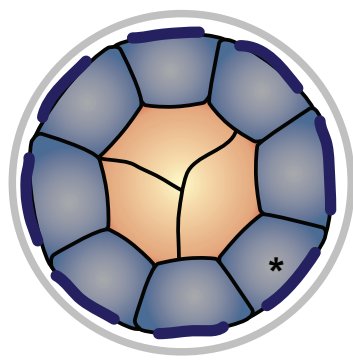

late 16-cell
Different division orientations and resulting daughter cells (dotted line represents cleavage furrow)

(1) gives rise to one polar outside and one apolar inside cell

(2) gives rise to two polar outside cells

(3) gives rise to one polar and one apolar outside cell

$\longrightarrow$ indicates cell internalization

* indicates repolarization

Fig. 3. Dynamic cell rearrangements at the morula stage. The cells of the 8-cell embryo divide with various angles - examples of different division orientations are shown as (1), (2) and (3). Dotted lines represent the cleavage planes of different divisions. Depending on the cleavage plane different daughter cell types are formed at the 16-cell stage-daughter cells can remain in contact with the outside surface or become engulfed by other cells. Additionally, they may or may not inherit part of the apical domain (in dark blue), resulting in polar (blue) and apolar (orange) cells, respectively. (1), (2) and (3) also indicate the progeny arising from different division orientations. During the 16-cell stage most apolar outside cells internalize, while the occasional apolar outside cell acquires de novo polarity $(*)$.

marage et al., 2015). The presence of a contractile actomyosin cortex in turn was reversely correlated with the presence of an AD (Anani et al., 2014; Maître et al., 2016) and transplanting an AD together with the underlying subcortical material onto an apolar cell kept it from getting internalized by a polar neighbor (Korotkevich et al., 2017). How exactly the AD regulates actomyosin contractility, however, remains to be solved.

These data argue that polarity dictates cellular rearrangements at the 16-cell stage, which for majority of cells is indeed the case. There are however, rare, apolar outside cells, which instead of internalizing stay on the surface and acquire a new AD (Anani et al., 2014; Korotkevich et al., 2017), thus in some cases a positional cue can override polarity. It is currently not known how the choice is made in an apolar outside cell to internalize or to repolarize. Prolonged exposure of apolar cells of an early blastocyst by removing the outside TE layer is known to result in repolarization (Handyside, 1978; Hogan \& Tilly 1978; Rossant \& Lis, 1979; Spindle, 1978; Stephenson et al., 2010). It may therefore be simply a matter of timing - is internalization or reestablishment of polarity faster?

Just prior to the next round of divisions, a roughly 4-5 apolar inside and 10-11 polar outside cell configuration is achieved, which more closely resembles ICM/TE ratios at the early-mid blastocyst stage. The 16-to-32-cell divisions can still perturb cell position and therefore future cell fate. Specifically, some outside cells can divide with an orientation that will push one of the daughters inside (Morris et al., 2010; Strnad et al., 2015; Watanabe, Biggins, Tannan, \& Srinivas, 2014; Yamanaka, Lanner, \& Rossant, 2010). However, there are conflicting data about how frequent such divisions are and whether the daughter cell pushed in by the division actually stays within or sorts back out to the surface (Strnad et al., 2015; Watanabe et al., 2014).

\section{Initiation of lineage-specific expression programs}

There are a number of transcription factors (TFs) characteristic of both ICM and TE lineages (Bissiere, Gasnier, Álvarez, \& Plachta, 2018). Notable examples include pluripotency factors Oct4, Sox2 and Nanog expressed in the ICM and Tead4, Cdx2, Gata3, Eomes, Tcfap2c and Elf5 in the TE. Examining protein expression by antibody localization showed that many of these lineage-specific
TFs were expressed initially at low levels in all cells of the embryo, followed by a gradual restriction and increase in expression level in respective lineages (Mitsui et al., 2003; Palmieri, Peter, Hess, \& Scholer, 1994; Ralston et al., 2010; Strumpf et al., 2005). Such gradual restriction in expression were also noted in single-cell gene expression profiling studies (Deng, Ramskold, Reinius, \& Sandberg, 2014; Guo et al., 2010; Posfai et al., 2017). Lineage specific transcriptional profiles of both ICM and TE emerged concomitant with the onset of morphogenetic changes among cells: at the 16cell stage cells still expressing a mixed signature are detected, however a number of cells already initiate ICM or TE expression profiles (Posfai et al., 2017). What initiates the divergence of these transcriptional programs?

To date the earliest ICM/TE segregation phenotype is the failure of TE lineage formation due to Tead4 disruption (Nishioka et al., 2008; Yagi et al., 2007). In Tead4 mutants ICM markers such as Oct4 (Nishioka et al., 2008; Yagi et al., 2007) and Sox2 (Wicklow et al., 2014) are ectopically expressed in outside cells and generation of an epithelial TE layer is compromised. In various other systems Tead proteins function together with co-activators Yes-associate protein (Yap) and Taz, that are regulated by the Hippo signaling pathway. When the Hippo pathway is active, the serine/threonine kinases Lats 1/2 phosphorylate Yap/Taz, causing their cytoplasmic retention (Fig. 4). On the other hand when the pathway is inactive, unphosphorylated Yap/Taz shuttle into the nucleus and interact with Tead4.

In the TE lineage the Hippo pathway is inactive, resulting in nuclear Yap localization and activation of TE-associated TFs, Cdx2 (Nishioka et al., 2008; Yagi et al., 2007) and Gata3 (Ralston et al., 2010), as well as other TE-associated genes, such as Dab2, Lrp2, Krt8, Krt18 (Posfai et al., 2017). Cdx2 plays a particularly important role in TE formation - embryos deficient in Cdx2 develop into blastocysts, however the blastocoel cavity collapses due to the lack of TE epithelial integrity and embryos fail to implant (Blij, Frum, Akyol, Fearon, \& Ralston, 2012; Strumpf et al., 2005). Cdx2 is required to repress Oct4 and Nanog expression, as $C d x 2$ mutant embryos continue to express these pluripotency factors in outside cells (Strumpf et al., 2005). In wild type 16-cell stage embryos initially low levels of Cdx2 are detected in all cells in a Tead4/ 
Yap-independent manner (Posfai et al., 2017; Yagi et al., 2007). However, as soon as Yap localization differences are detected amongst blastomeres, Cdx2 levels start to show a positive correlation with nuclear Yap levels, suggesting that Hippo signaling differences ignite lineage segregation by inducing target gene expression in TE progenitors. On the other hand Hippo signaling is active in the ICM lineage, Yap is retained in the cytoplasm and cannot activate Tead4dependent transcription.

A number of studies have reported various molecular differences present between 2 or 4-cell stage blastomeres, and have initiated a debate whether these differences are functionally relevant for biasing ICM/TE cell fate decisions later on (Burton et al., 2013; Goolam et al., 2016; Plachta et al., 2011; Torres-Padilla, Parfitt, Kouzarides, \& ZernickaGoetz 2007; White et al., 2016; and recently reviewed in Chazaud, \& Yamanaka, 2016). While the possibility of a pre-existing bias is intriguing, it is clear that up to the 8-cell stage blastomeres are plastic and can respond to cues promoting either cell fate.

\section{Linking position and polarity with Hippo signaling}

How are different Hippo activities achieved in ICM and TE progenitor cells? A scaffolding protein called Angiomotin (Amot) is necessary to recruit Hippo pathway members to AJs, leading to Hippo activation (Cockburn, Biechele, Garner, \& Rossant, 2013; Hirate \& Sasaki, 2013; Leung, \& Zernicka-Goetz, 2013). All cells in the embryo express Amot and have AJs along cell-cell contacts, therefore this alone does not explain Hippo signaling differences. Interestingly, Amot is also able to bind subcortical F-actin underlying the AD (Hirate \& Sasaki, 2013). In fact, in polarized outside cells Amot is sequestered from AJs, and becomes exclusively localized to the apical membrane. At the apical membrane Amot does not assemble Hippo members resulting in no Hippo activity. Therefore polarity differences dictate Amot localization and Hippo activity. Indeed, a closer look at the 16-cell stage revealed that apolar outside cells had cytoplasmic Yap, thus Yap localization correlated with polarity status rather than cell position (Anani et al., 2014; Maître et al., 2016). The molecular explanation for this polarization-dependent F-actin-binding of Amot is a key missing piece.

\section{Cavitation}

During the 32-cell stage cavity formation is initiated in the embryo (Fig. 5). First, small intracellular fluid-filled vacuoles appear in the TE layer, which are then deposited by exocytosis into intercellular spaces (Watson, Natale, \& Barcroft, 2004). Fluid initially accumulates in multiple small cavities between inner cells, which then fuse to form one large cavity that compresses the ICM to one side. A tightly sealed epithelial TE, $\mathrm{Na}^{+} / \mathrm{K}^{+}$ATPase pumps and aquaporins are needed for fluid accumulation (Watson, Natale, \& Barcroft, 2004). $\mathrm{Na}^{+} / \mathrm{K}^{+}$pumps in the basolateral membranes of TE cells establish an ion gradient, which then drives water uptake through aquaporins in the TE. The sealing of the TE layer has long been known to involve AJs and tight junctions (TJs). Recently, live imaging was used to show that F-actin rings form under the apical membranes of cells at the morula stage (Zenker et al., 2018). A polarized microtubule network, originating from the disassembled spindle from the previous division, underlays the AD and inhibits

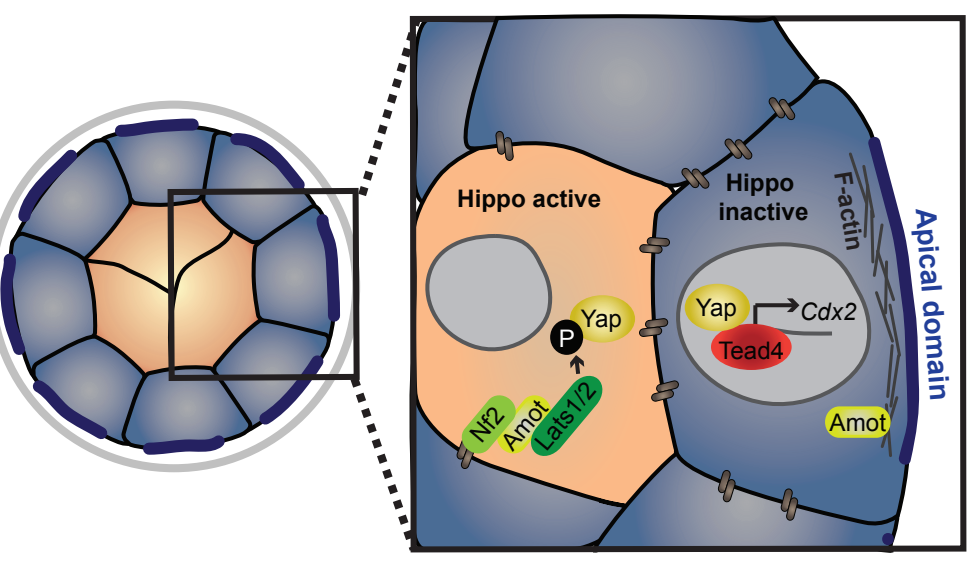

Fig. 4. Differential Hippo signalling activity in trophectoderm (TE) and inner cell mass (ICM) progenitors. In apolar ICM cells several Hippo pathway members (Nf2, Amot and Lats 1/2 kinases) assemble at adherens junctions (AJs) and activate signaling. Lats $1 / 2$ phosphorylate the transcriptional coactivator Yap, which retains Yap in the cytoplasm. In TE cells Amot is sequestered away from AJs by binding the F-actin network underlying the apical domain and therefore an active Hippo complex can not assemble. Unphosphorylated Yap shuttles into the nucleus and ogether with Tead4 activate transcription of key TE-specific genes, such as Cdx2.

F-actin accumulation, forcing it to build a ring around the AD. Downregulating Pard6b disrupted ring formation (Zenker et al., 2018) and inhibiting aPKC delayed cavitation (Eckert et al., 2004). At the morula stage, the F-actin rings expand towards cell-cell junctions, meet, and couple between neighboring cells and then zipper along the entire length of the junction. Both ring binding and zippering was found to be dependent on local myosin II accumulation, suggesting these processes are tension-dependent. Moreover, zippering was found to be necessary for junction maturation and sealing of the epithelium. It will be important to distinguish the molecular composition of non-contractile actin rings of polar cells required for embryo sealing from the contractile subcortical actin network driving compaction and internalization of apolar cells at the 8- and 16-cell stages, respectively.

\section{Mechanical forces}

An area that has so far received little attention in the embryo is the effect the mechanical environment has on lineage development and patterning. This is a particularly relevant question, as Hippo signaling and Yap have been shown to regulate differentiation by transducing mechanical stimuli through the actomyosin cytoskeleton (Halder, Dupont, \& Piccolo, 2012). It is clear that position and polarity-dependent inputs regulate Hippo signaling in the embryo, but is there more to this regulation?

At the 16-cell stage dynamic cell rearrangements are due to differential intracellular contractility of cells. Inhibiting myosin contractility increases cytoplasmic Yap and mimics ICM-like Yap distribution; therefore contractility in principle has an effect on Yap localization (Maître et al., 2016). However, in intact embryos Yap was found to be mainly cytoplasmic in internalizing contractile cells and nuclear in outside cells with low contractility. It is therefore currently unclear whether Yap is indeed regulated by intracellular contractility at this stage.

As cells sort to the inner compartment, the remaining outside cells need to deform and stretch to form a continuous epithelial layer 
A Cavitation

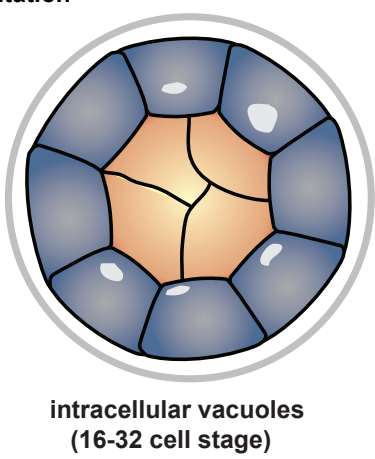

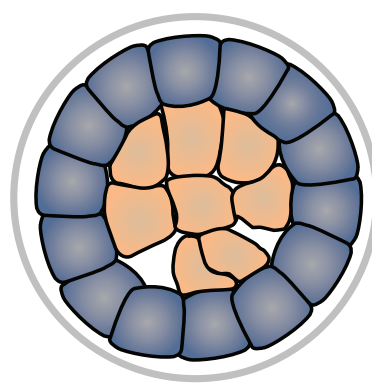

intercellular cavities (32-cell stage)

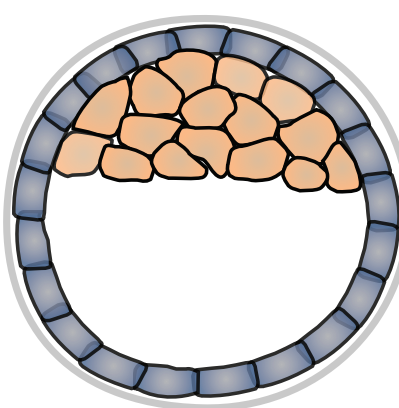
(64-cell stage) blastocoel cavity

Fig. 5. Embryo cavitation. (A) The first signs of fluid accumulation in the embryo appear as intracellular vacuoles in TE cells. These vacuoles are emptied into spaces between ICM cells and eventually fuse to form one large blastocoel cavity. (B) For fluid to accumulate a tightly sealed epithelial TE layer is needed. Sealing of the TE involves non-contractile actin rings forming under the apical cortex. These rings expand until they reach the cell boundary and rings of neighbouring cells couple by binding to adherens (brown) and tight (red) junctions. Rings zipper along the entire cell boundary and recruit additional adherens and tight junctions. on the surface. Cell stretching is further boosted during cavitation, when hydrostatic pressure builds up in the fluid-filled cavity and presses on the TE layer. It will be interesting to examine whether stretching influences Yap localization and therefore cell fate. Cells which develop without any contact, develop a gene expression profile that more closely resembles TE rather than ICM cells (Lorthongpanich, Doris, Limviphuvadh, Knowles, \& Solter, 2012). A TE-like state is in line with cells being exposed to the outside environment. Curiously however, the gene expression pattern of these cells is still distinct from TE cells, raising the possibility that mechanical stretch may indeed be needed for the acquisition of a full TE profile.

\section{Plasticity}

An interesting problem that has engaged developmental biologists for decades is when and how the emerging lineages lose their ability to morph into the other cell type. The timing of commitment has been explored by numerous studies (Fig. 6), and has recently been revisited using new tools to identify progenitors of the two developing lineages (Posfai et al., 2017). Interestingly, specification and commitment arises simultaneously in the developing TE, with some TE cells emerging already at the 16-cell and most set aside by the early 32-cell stage. In the developing ICM lineage however, a developmental window separated specification and commitment: most ICM cells specified by the early 32-cell stage, however they were still able to convert to TE up to the 64-cell stage. Commitment of the TE lineage first may reflect the developmental urgency of producing a cell type that will ensure implantation. On the other hand, retaining plasticity in the ICM up to the mid blastocyst stage could serve as a backup mechanism to replenish the TE, if necessary. Loss of plasticity in the ICM coincided with the initial appearance of EPI and PE transcriptional profiles, suggesting a functional relationship between loss of TE potential and initiation of EPI/PE differentiation. Indeed, Wigger et al., showed that by inhibiting Fgf and downstream Extracellular signal-regulated kinase
(ERK) signaling, the pathway that is required for the segregation of EPI and PE cells, plasticity of ICM cells could be extended towards the TE lineage (Wigger et al., 2017). Further studies are clearly needed to identify the molecular mechanisms underlying cell fate commitment.

\section{Lineage crosstalk and trophoblast stem cells}

Trophoblast vesicles can form from cells that are committed to the TE lineage. These empty vesicles can occasionally initiate implantation, albeit at low frequencies (Surani \& Barton, 1977). This highlights the importance of sustained crosstalk between the ICM and TE lineages. A number of differentially expressed receptor and ligand pairs have been observed between ICM and TE lineages, providing clues to the molecular mechanisms underlying inter-lineage communication. Most notably, Fibroblast growth factor (Fgf) ligands produced by the ICM, in particular Fgf4, activate ERK signaling in the TE through Fgf receptors and stimulate TE proliferation (Nichols, Silva, Roode, \& Smith, 2009). Mutations in Fgf4 or its associated receptor Fgfr2, lead to peri-implantation embryonic lethality and poor trophoblast development (Arman, Haffner-Krausz, Chen, Heath, \& Lonai, 1998; Feldman, Poueymirou, Papaioannou, DeChiara, \& Goldfarb, 1995). In addition, treatment of blastocysts that lack an ICM with Fgf4 increases TE proliferation (Chai et al., 1998; Nichols et al., 1998). Thus, proliferation of the TE is maintained, in part, by a source of Fgf4 originating in the ICM. Given its propensity to divide, the TE overlaying the ICM and its later derivative, the extraembryonic ectoderm (ExE), contain a pool of trophoblast stem (TS) cells (Fig. 1). Indeed, it is possible to derive TS cells in vitro from blastocyst outgrowths as well as from the ExE in the presence of Fgf4 (Tanaka et al., 2002).

Maintenance of TS cells also requires additional stimulants such as members of the TGF- $\beta$ superfamily, Activin and Nodal (Erlebacher, Price, \& Glimcher, 2004) and embryos that lack Nodal show developmental defects in the placenta (Ma et al., 2001). Bone morphogenetic protein (Bmp) ligands and TGF- $\beta$ family members 
Fig. 6. Summary of studies examining the potential of inner cell mass (ICM) and trophectoderm (TE) cells. Overview showing the developmental potential of ICM (later epiblast (EPI) and primitive endoderm (PE)) and TE progenitors at different embryonic stages. Developmental potential was examined by either adding a single cell to a host morula or to host cells and assaying which lineage the single cell contributed to (morula aggregation assay) (Grabarek et al., 2012; Posfai et al., 2017; Rossant \& Vijh, 1980; Tarkowski, Suwinska, Czołowska, \& Ożdżeński, 2010) or by creating an entire embryo from the same type of progenitors and assaying whether the other cell type could be re-formed (Handyside, 1978; Posfaiet al., 2017; Rossant \& Lis, 1979; Spindle, 1978; Stephenson et al., 2010; Suwińska, Czołowska, Ożdżeński, \& Tarkowski, 2008; Ziomek, Johnson, \& Handyside, 1982). Creating an embryo from only ICM cells can be achieved by removing the TE layer using immunosurgery. Alternatively single ICM or TE cells can be re-aggregated to make entire embryos.

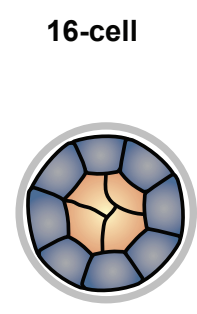

32-cell

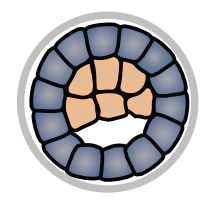

64-cell blastocyst

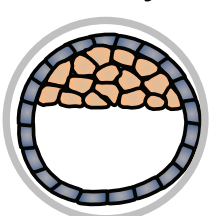

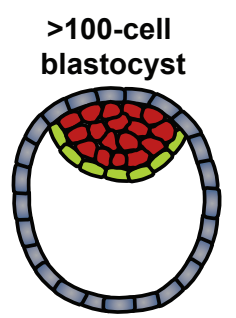

$\square$ still have TE potential $\square$ lost TE potential

Handyside, J.Embryol.Exp.Morph.1978

$\square$ still have TE potential $\square$ still have TE potentia

$\square$
Spindle, J.Exp.Zool.1978

$\square$ still have TE potential $\square$ still have TE potential

Hogan and Tilly, J.Embryol.Exp.Morp. 1978

$\square$ still have TE potential $\square$ lost TE potential

Rossant et al, Dev Biol 1979

still have ICM potential

Rossant et al, Dev Biol 1980

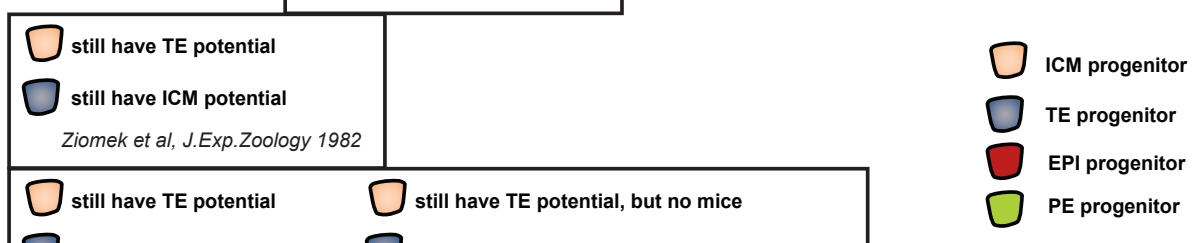

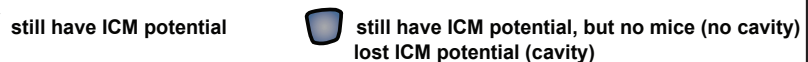
Suwinska et al, Dev Biol 2008

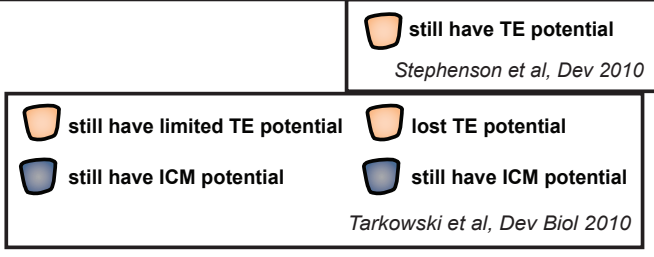

Tarkowski et al, Dev Biol 2010

Grabarek et al, Development 2012

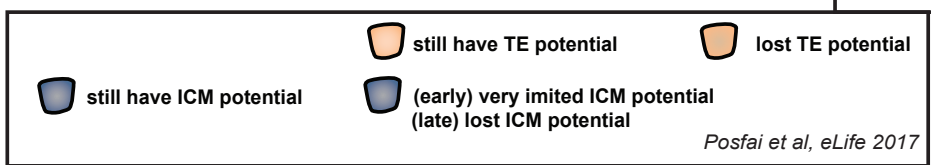

produced by the ICM are needed for generating correct TE cell numbers in the embryo (Graham et al., 2014).

Interestingly, in a recent publication researchers devised a protocol to assemble TS and embryonic stem (ES) cells, a stem cell type derived from the ICM, into structures resembling a blastocyst (Rivron et al., 2018). Comparing expression profiles of "TE" and "ICM" cells from these so-called blastoids with cultured TS and ES cells identified Bmp and Nodal signaling as inductive cues sent by the ICM to the TE for the generation of an implantationcompetent TE.

\section{Mural/polar differentiation of trophectoderm}

By the mid blastocyst stage of murine embryo development, the already specified TE is clearly segregated into two distinct subtypes based on its proximity to the ICM - the polar TE that is in direct contact with the ICM, and the mural TE, which surrounds the blastocoel. The mural TE of the late blastocyst attaches to the maternal endometrium and initiates embryo implantation. Following implantation, mural TE cells progressively stop dividing and instead begin to endoreduplicate DNA, forming large, polyploid primary trophoblast giant cells (TGCs) (Varmuza, Prideaux, Kothary, \& Rossant, 1988). Primary TGCs are highly invasive cells that facilitate implantation by secreting proteases, including cathepsins and metalloproteinases, which help to invade the surrounding maternal tissue (Screen, Dean, Cross, \& Hemberger, 2008, Alexander et al., 1996). In contrast, the polar TE cells overlying the ICM continue to proliferate and give rise to all of the trophoblast lineages that make up the mature placenta (Copp, 1979). Withdrawal of Activin/Nodal as well as Fgf4 in vitro results in down-regulation of TS cell-specific TFs and terminal differentiation into TGCs. This supports the no- 
A

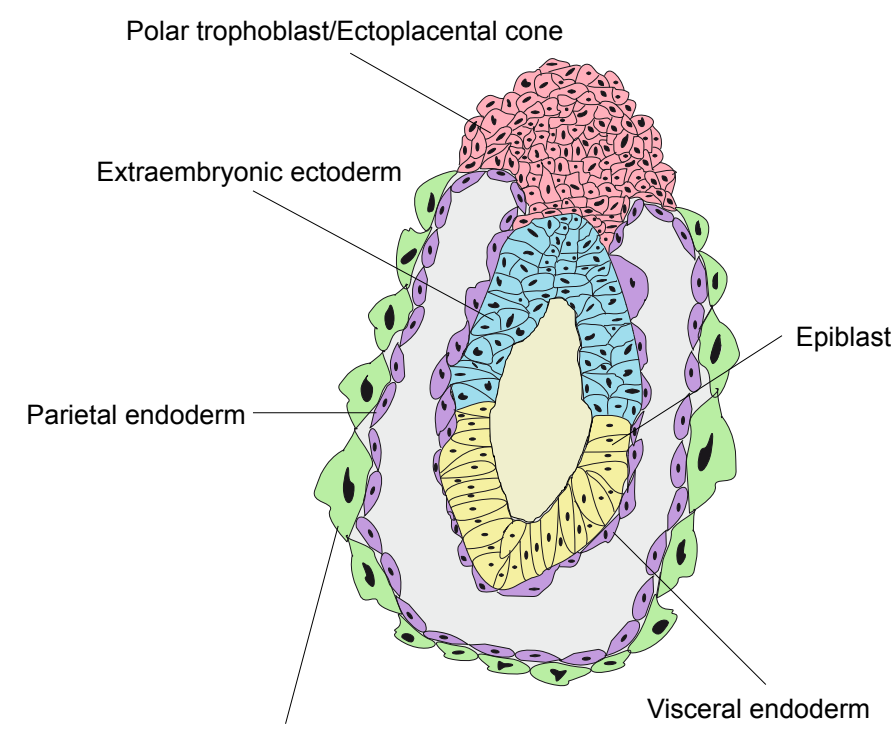

Mural trophoblast/Trophoblast giant cell
Embryonic pole

B

\section{E9.5 human embryo}

Primitive syncytiotrophoblast

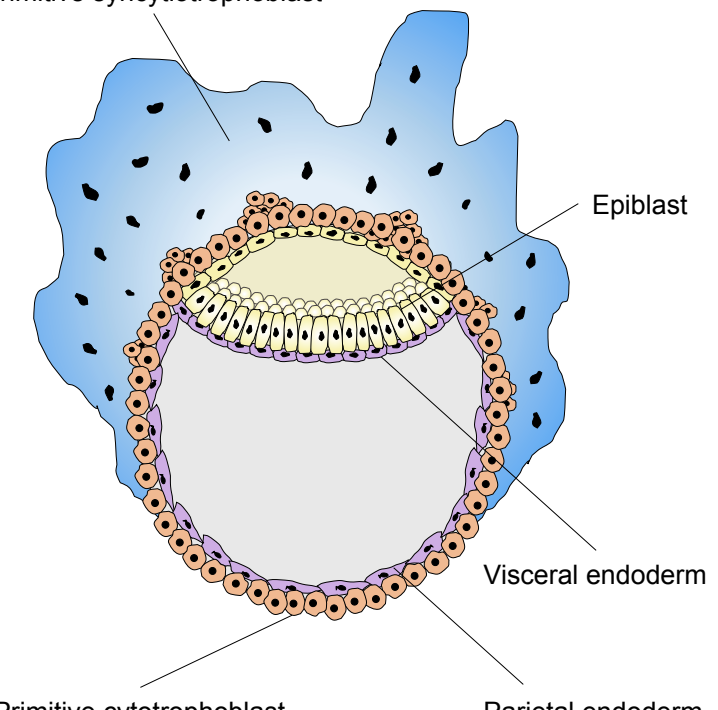

Primitive cytotrophoblast

Parietal endoderm

\section{Abembryonic pole}

Fig. 7. Comparison of trophoblast lineages of the mouse and human early post-implantation embryo. (A) Egg cylinder stage mouse embryo at embryonic day (E)6.5. Continuous proliferation of the polar TE gives rise to the extraembryonic ectoderm (ExE) and invading ectoplacental cone. The mural TE stops dividing and differentiates into trophoblast giant cells (TGCS). Note the absence of syncytiotrophoblast cells in the post-implantation mouse embryo. (B) Implanted human embryo at (E)9.5. In humans, the TE gives rise to the primitive cytotrophoblast (CT) that surrounds the entire embryo and the multinucleated primitive syncytiotrophoblast (ST) that start forming from the TE at the embryonic pole.

tion that in vivo, the mural TE cells that are further away from the ICM stop proliferating and differentiate into TGCs partially due to insufficient activation of Fgf, Activin and Nodal signaling.

While there have been extensive studies analyzing postimplantation development of polar and mural TEs, not much is known about the differences between these two lineages prior to implantation. Analysis of the transcriptional profile obtained from polar and mural cells of the late blastocyst found hundreds of genes differentially expressed between these two lineages (Nakamura et al., 2015). While polar TE cells were enriched in GO terms such as 'mitotic cell cycle' and 'cell division', mural TE cells were characterized by 'lipid storage', 'membrane organization', and 'cell death' pathways. Such gene signatures suggest that the mural TE already exhibits transcriptional characteristics of differentiated TGCs, including cell cycle exit. A recent study identified several TS cell-enriched microRNAs (miRNAs), including miR-15b, that are capable of inducing trans-differentiation of ES cells into a trophoblast-like lineage with a mural-TE phenotype (Nosi, Lanner, Huang, \& Cox, 2017). These induced trophoblast cells showed exclusive localization to the mural TE when injected into preimplantation embryos. Furthermore, gene signature of these cells confirmed expression of primary TGC markers. This again emphasizes the idea that TE differentiation is compartmentalized and influenced by signals from the ICM.

In addition to the transcriptional differences between polar and mural TEs, functional differences between these two TE subtypes also exist. This is elegantly reflected in cellular responses of the TE during diapause. Embryonic diapause, a state when implantation is suspended for a period of time (dormancy) until optimal conditions for implantation are achieved (reactivation), has been used for mapping metabolic responses in the blastocyst. Proteins found to be up-regulated in reactivated, implantation competent blastocysts, most related to mitochondrial function (Atp5b) and endo-lysosomal activity (CtsD), were significantly enhanced in the mural TE (Fu et al., 2014). In addition, the mural TE contains more multi vesicular bodies, indicative of increased phagocytosis (Rassoulzadegan, Rosen, Gillot, \& Cuzin, 2000), needed to clear up endometrial cell debris during implantation. Exposure of the blastocyst to Fgf4 in culture resulted in the inhibition of phagocytosis in the mural TE, suggesting that Fgf signaling may also control functional behaviour of the TE beyond regulation of stemness. These studies highlight the heterogeneous nature of the TE, and reveal differences between polar and mural TE function.

\section{Trophectoderm development in human embryos}

\section{Trophectoderm and inner cell mass segregation}

Fertilization and preimplantation development is an accessible phase of embryonic development, making it a time frame when interventions can be made to help couples with fertility issues. Improvements have been made in human assisted reproduction techniques (ART) over the past decades, however the implantation rate of in vitro generated embryos still remains relatively low and is considered the main hurdle for the success of ART (Munne et 
al., 2017, Spinella et al., 2017).

Overall blastocyst morphology and the events of compaction, formation of an epithelial TE layer and cavitation all resemble the morphogenetic events observed in the mouse, with the general rule that everything happens at a slightly higher cell number in human - for example compaction takes place at the 16-cell stage, cavitation around the 64-cell stage (Cockburn, \& Rossant, 2010). However, examining the expression of key lineage regulators has already revealed fundamental species-specific differences. CDX2 is expressed markedly later in the human TE, only after blastocoel formation (Niakan \& Eggan, 2013). EOMES and ELF5 were undetectable and TCFAP2C was expressed also in the ICM (Blakeley et al., 2015). Instead, human TE identity was characterized by robust expression of GATA 2/3, DAB2, EFNA1, PPARG, FHL2, KRT18/8 and TEAD3 (Stirparo et al., 2018). The pluripotency marker OCT4 persisted longer in the TE, and was only restricted to ICM shortly before implantation (Niakan \& Eggan, 2013). A recent study used CRISPR/Cas 9 editing to generate POU5F1 (gene encoding OCT4) deficient human embryos and found that unlike in mouse where only the ICM is compromised without Oct4, in human both TE and ICM lineages were affected (Fogarty et al., 2017). This study exemplifies that different expression patterns reported in human lineages will likely have different functional roles as well.

Consistent with the later restriction of CDX2/OCT4 to appropriate lineages, single cell RNA-sequencing on human embryos revealed that segregation of lineage-specific profiles similarly only took place after blastocyst formation (Petropoulos et al., 2016). Thus there is a clear difference in timing of lineage segregation. Moreover, all three lineage profiles segregated nearly synchronously, unlike the two consecutive lineage decisions in mouse. These observations question whether the central signaling pathways identified in mouse, Hippo/Yap in TE/ICM and Fgf/ERK signaling in EPI/PE segregation, function in human. While Yap is expressed throughout human preimplantation development (Yan et al., 2013; Yu et al., 2016), it appears nuclear in both TE and ICM cells (Qin et al., 2012). Inhibiting Fgf signaling had no apparent effect on EPI and PE segregation (Kuijk et al., 2012; Roode et al., 2012). Further studies are clearly needed to address human-specific regulatory mechanisms of preimplantation lineage formation.

\section{Trophectoderm maturation}

Unlike in the mouse embryo, in which implantation is initiated by the mural TE, attachment and implantation of the human blastocyst occurs via the polar TE, near the ICM (Gamage, Chamley, \& James, 2016). Following implantation, human TE cells begin to differentiate into primitive mononuclear cytotrophoblast (CT) and primitive multinucleated syncytiotrophoblast (ST). Based on existing images of early postimplantation human embryos (Gasser et al., 1975), the primitive syncytium is believed to originate from fusion of cytotrophoblast cells all over the TE in the implanted human blastocyst. Eventually syncytial cells continue to be replenished from underlying proliferative cytotrophoblast cells in a perpetual cycle of fusion and cell debris extrusion. Thus, it is clear that primitive syncytial cells in human are morphologically distinct from ExE cells of mouse, which are formed by rapid proliferation of polar TE (Fig. 7). Why distinct cellular behaviour patterns exist between these two species is a mystery. However, such divergent biology begs the question as to whether what we currently know about TE differentiation and implantation in mice also pertains to human embryos.

At the late blastocyst stage the human TE also contains two transcriptionally distinct populations of cells; presumably polar and mural TE cells (Petropoulos et al., 2016). Of the genes that were most differentially expressed, several have previously been associated with ST differentiation, and likely reflect the polar TE population. However, this study did not perform RNA sequencing on individually isolated polar and mural TE cells, thus we cannot exclude the possibility that within both of these distinct groups there are clusters of cells with high stem cell potential.

The TE of human blastocysts has also been shown to have functional properties that differ between polar and mural cells. Phagocytic activity was increased at the polar TE (Y. Li, Xu, Zhou, Zhang, \& Zhuang, 2016) and corresponded with the site of attachment, with several cell adhesion and extracellular matrix proteins showing localized increase in TE expression (Aberkane et al., 2018).

It is clear that the polar and mural TE cells-both human and mouse-exhibit transcriptional and functional characteristics that presage the functional aspects of their post-implantation trophoblast derivatives. In both cases, the implanting regions of the TE exhibit heightened phagocytic properties that promote embryo attachment and implantation into the uterus. From transcriptome studies it is obvious that while the murine TE exhibits increased expression of TGC genes, the human TE has increased expression of ST genes. This likely reflects difference in the biology of initial stages of adhesion (mural vs polar TE) and subsequent immediate differences in implantation (syncytialization vs. robust proliferation).

\section{Human trophoblast stem cells}

The derivation of mouse TS cells 20 years ago has allowed for further and more detailed investigation of the molecular events that underlie normal murine placental development. Establishment of a human counterpart of these cells has proven to be difficult. Early attempts to derive human TS cells using mouse protocols have been unsuccessful (Kunath et al., 2014). This is likely due to differences in the signaling pathways that control early TE differentiation and maintenance of the TS population in human versus mouse embryos. Indeed, in vitro culture of human blastocysts with FGF4/heparin and human embryonic fibroblasts failed to support derivation of TS cells (Kunath et al., 2014). In addition, FGFR2 has been shown to be virtually undetectable in human blastocysts (Kunath etal., 2014). Thus, unlike in mouse, maintenance of human TS cells is not dependent on Fgf4 signaling. Additional attempts to derive human TS cells have focused on culturing isolated primary CT cells from first-trimester placentas. CT cells are a proliferative, undifferentiated population of cells that give rise to two terminally differentiated cell types- the extravillous cytotrophoblast (EVT) and the ST (Soncin, Natale, \& Parast, 2014) and have some stemlike properties. EVTs are invasive cells, often containing polyploid nuclei that can facilitate embryo implantation or remodel maternal arteries later in gestation. The ST are multinucelated cells that are in direct direct contact with the maternal blood and mediate gas, nutrient and waste exchange between the mother and fetus. These two cell types are analogous to the murine TGCs and syncytial trophoblast cells of the labyrinth, respectively. However, while CT can be isolated from early placentas, they cannot be maintained in vitro (L. Li \& Schust, 2015). In light of this problem, several groups have attempted to create trophoblast cell lines using other methods, including immortalization of isolated CT cells 
or differentiation of human embryonic stem cells into trophoblast (Gamage et al., 2016). Presumptive trophoblast progenitor lines were established from the first-trimester chorion (Genbacev et al., 2011), and from stem cells derived from pre-compaction human blastomeres (Zdravkovic et al., 2015). However, all of these lines failed to resemble human trophoblast cells transcriptionally, molecularly and/or morphologically.

Due to the lack of proper guidelines for identifying trophoblast cells in vitro, Lee et al., compiled a list of criteria used to aid the classification of primary trophoblast/CT cells (Lee et al., 2016). These include the expression of trophoblast-specific proteins (GATA3, TFAP2C and KRT7), an appropriate HLA class I profile, observed hypomethylation of the ELF5 promoter, and the expression of microRNAs (miRNAs) from the chromosome 19 miRNA cluster (C19MC). Previously reported human TS-like cell lines did exhibit some feature of CT cells, however they failed to display all four required hallmarks. Recently, however, human TS cells that fall within all of these guidelines have been derived. Successful derivation of human TS cells from both blastocysts and isolated placental CT cells has been accomplished (Okae et al., 2018). These cells were capable of proliferating in culture for at least 5 months as mononuclear epithelial cells, and could differentiate into EVTs and STs under specific growth conditions. The culture conditions for these TS cells were selected based on transcriptomic analysis of CT cells isolated from first-trimester placentas. The analysis revealed an overrepresentation of Wingless/Integrated and epidermal growth factor pathways, indicating that these factors may be essential for maintaining CT cells in their undifferentiated proliferative state. In addition, ROCK, TGF- $\beta$ and histone deacetylase inhibitors were used to enhance attachment and boost proliferation. As expected, the signalling pathways required for maintaining human TS cells differ substantially from those that regulate mouse TS cell renewal. Considering differences in the behaviour of mouse and human TE during implantation, it is not surprising that distinct signaling pathways are used to achieve the same biological outcome.

\section{A clinical outlook}

Post-implantation development is a considerable investment from the mother's side, thus quality control of embryos before implantation may be a good way to avoid sacrificing resources for nonviable embryos. Several factors contribute to the success of implantation of human embryos, and can be used as predictors of implantation success in clinical settings A combination of hallmarks are taken into account when making a decision which embryo to transfer including the rate of development (timing of cavitation and expansion), appearance and size of the ICM, size of blastocoel and zona thickness. However, morphological appearance of TE cells alone has been used as a successful indicator of live birth after the transfer of a single human blastocyst (Ahlstrom, Westin, Reismer, Wikland, \& Hardarson, 2011) and a few molecules produced by TE were explored as possible biomarkers, albeit with variable success.

TEcells are a source of crucial pregnancy-associated hormones, otherwise associated with the mature trophoblast of the placenta. $\beta$-hCG and pregnancy specific $\beta 1$-glycoprotein (Jurisicova, Antenos, Kapasi, Meriano, \& Casper, 1999) are used to signal the arrival of the conceptus to the mother, and are detected in culture medium of human embryos, albeit at variable levels. In addition, the mural TE also maintains patchy expression of HLA-G (De Paepe et al., 2013; Jurisicova, Casper, MacLusky, Mills, \& Librach, 1996), a molecule involved in the immunoprotection of invasive trophoblast against maternal natural killer cells. It is tempting to speculate that HLA-G could be marking regions with early invasive extravillous trophoblast buds, which initiate proliferation at syncytialized implantation sites. Secreted HLA-G has been shown to correlate with implantation potential, however a large study failed to find such association at all participating fertility centres (Tabiasco et al., 2009). Expression of chemokine receptor type 4 (CXCR4) by the TE has been shown to contribute to implantation success of human embryos (Bao et al., 2016). Although the mechanism has not been fully elucidated, bioinformatic analysis suggested that CXCR4 may activate Rho pathway to promote TE apoptosis, migration, or may affect polarity to maintain TE fate.

Furthermore, implantation-competent TE modulates endometrial receptivity by communicating with uterine cells. TE cells are a source of at least 38 miRNAs, two of which (miRNA20a and miRNA30) can be identified in spent culture medium of human blastocysts with high implantation potential, but not earlier cleavage stage embryos (Capalbo et al., 2016). These miRNAs are predicted to modulate expression of genes involved in endometrial cell growth and are implicated in the process of implantation.

In addition, euploidy rates are used to eliminate those embryos that are chromosomally imbalanced. For this procedure, a few cells from the TE are biopsied by herniation at the site opposite to the ICM. The most predictive marker of euploidy even at the blastocyst stage is maternal age - higher the age, higher the proportion of aneuploid embryos (Piccolomini et al., 2016). However, the biggest headache for most of the clinicians when interacting with patients is the decision whether to use mosaic embryos, containing TE cells with variable genetic rearrangements, which are not always concordant with ploidy of the ICM (J. Huang, Yan, Lu, Zhao, \& Qiao, 2017; Taylor et al., 2016). The degree of mosaicism in the TE is a relatively poor predictor of ongoing pregnancy outcomes (Kushnir, Darmon, Barad, \& Gleicher, 2018). Whether these inconsistencies reflect technical limitations of detection or whether they speak of the biology of TE function, is currently unclear. TE cells have a forgiving nature towards their DNA content. Moreover, the TE, which later gives rise to the CT of the placenta, is not a homogenous compartment of cells. These CT progenitors acquire aneuplodies as they differentiate into a more invasive phenotype (Weier et al., 2005). From studies of murine tetraploid embryos used to rescue a placental phenotype as well from human chorionic villi sampling (Grati et al., 2014) it is clear that aneuploid cells can function in extraembryonic tissues without interfering with euploid embryo development. Giant cells in mouse placentas have a high nuclear DNA content ( 162N) (Sher et al., 2013) and specific chromosomal regions containing genes relevant to placental function are amplified in trophoblast cells (Hannibal \& Baker, 2016). This unique cellular approach utilized by a small number of invasive cells serves as a mechanism used during early placentation to produce large quantities of transcripts driving hormonal production needed for maintenance of pregnancy. Recently, amplified/lost regions on several chromosomes were found in human placentas with normal babies but with placental pathologies (Leavey et al., 2016). However, it is not clear when these changes start occurring in development and whether they could be detected already in the mural TE of the blastocyst. It is also possible that a population of invasive trophoblast progenitors in the TE may already exhibit signs of aneuploidy as they begin to differentiate. The question therefore 
still remains as to whether or not a relatively small sample of TE can accurately represent all the different cell types of the embryo.

In addition to nuclear DNA, cell biopsies contain smaller sized (16Kb), but much more abundant mitochondrial (mt)DNA. mtDNA copy number in TE biopsies (so called Mitoscore) became the latest trendy diagnostic tool used by some clinics to determine which blastocyst is the most likely to implant. Several independent studies found an association between maternal age, ploidy, implantation potential and mtDNAcontent in TE biopsies. mtDNAcopies become elevated with increasing maternal age in both chromosomally normal and abnormal blastocysts (Fragouli et al., 2015). The cause of elevated mtDNA has not been established, however it may reflect the higher energy demands of compromised embryos (Fragouli $\&$ Wells, 2015). At the present time it is unclear if similar differences occur in the ICM compartment or if the mtDNA copies are increased only in TE lineages of developmentally less competent embryos. In addition, it is also unclear if increased mtDNA reflects increased mitochondrial organellar number, premature onset of mtDNA replication, defective distribution during earlier cleavage stages or elevated endowment in oocytes from which they were conceived. However, it is clear that with TE commitment, mitochondria, which are immature and relatively quiescent during early stages of development, transition to elongating, less electron dense organelles with better defined cristae. This morphological transition is associated with higher mitochondrial activity, initiation of mtDNA replication and increased energy demands of the TE compared to the ICM (Sun \& St John, 2016). Interestingly, at least in mouse not all TE cells appear equal in terms of mitochondria. TE cells further away from the ICM contain more active mitochondria, compared to the polar TE with elevated expression of nutrient transporters and ATP generating pathways (Fu et al., 2014; Houghton, 2006). If these changes are similarly reflected in human TE or if species differences exist due to initial contact during implantation is currently unknown.

Many questions related to TE lineage commitment and biology are known in mouse but remain unexplored in human due to ethical concerns around the use of human embryos in research. A comprehensive study of cleavage patterns and localization of molecules regulating TE commitment to transfer the knowledge from mouse to human will likely not be feasible, but key factors should be assessed. Despite differences in signaling pathways used by early TE between these two species, studies assessing impact of chromosomal mosaicism and TE mitochondrial function in mouse would help to validate biological interpretations of these outcomes in human. Understanding the processes that regulate lineage formation, with the emphasis on understanding TE development and functionality could improve implantation rates by translating this knowledge into optimized culture conditions during ART or providing guidelines for selecting the fittest embryo for implantation.

\section{Acknowledgements}

Authors would like to thank Dr. Janet Rossant for comments during preparation of manuscript and Katherine Szelag for help with drawing of murine post implantation embryos. Work in Jurisicova's laboratory is supported by grants from NSERC and CIHR.

\section{References}

ABERKANE A, ESSAHIB W, SPITS C, DE PAEPE C, SERMON K, ADRIAENSSENS T, MACKENS S, TOURNAYE H, BROSENS JJ, VAN DE VELDE H (2018). EX- pression of adhesion and extracellular matrix genes in human blastocysts upon attachment in a 2D co-culture system. Mol Hum Reprod 24: 375-387.

ADJUK A, ZERNICKA-GOETZ M (2016). Polarity and cell division orientation in the cleavage embryo: from worm to human. Mol Hum Reprod 22: 691-703.

AHLSTRM A, WESTIN C, REISMER E, WIKLAND M, HARDARSON T (2011). Trophectoderm morphology: An important parameter for predicting live birth after single blastocyst transfer. Hum Reprod 26: 3289-3296.

ALEXANDER CM, HANSELL EJ, BEHRENDTSEN O, FLANNERY ML, KISHNANI NS, HAWKES SP, WERB Z (1996). Expression and Function of Matrix Metalloproteinases and Their Inhibitors at the Maternal-Embryonic Boundary During Mouse Embryo Implantation. Development Vol 122: 1723-1736.

AMANO M, NAKAYAMA M, KAIBUCHI K (2010). Rho-kinase/ROCK: A key regulator of the cytoskeleton and cell polarity. Cytoskeleton 67: 545-554.

ANANI S, BHAT S, HONMA-YAMANAKA N, KRAWCHUK D, YAMANAKA Y (2014). Initiation of Hippo signaling is linked to polarity rather than to cell position in the pre-implantation mouse embryo. Development 141: 2813-2824.

ARMAN E, HAFFNER-KRAUSZ R, CHEN Y, HEATH JK, LONAI P (1998). Targeted disruption of fibroblast growth factor (FGF) receptor 2 suggests a role for FGF signaling in pregastrulation mammalian development. Proc Natl Acad Sci USA 95: 5082-5087.

BAO S, LI T, LONG X, ZHANG J, ZHAO H, REN Y, ZHAO Y, LI R, TAN T, YU Y, QIAO J (2016). Chemokine Receptor Type 4 Regulates Migration and Invasion of Trophectoderm Cell in the Human Blastocyst. Biol Reprod 95: 21-21.

BISSIERE S, GASNIER M, ALVAREZ YD, PLACHTA N (2017). Cell Fate Decisions During Preimplantation Mammalian Development, 1st ed. Elsevier Inc.

BLAKELEY P, FOGARTY NME, DEL VALLE I, WAMAITHA SE, HU TX, ELDER K SNELL P, CHRISTIE L, ROBSON P, NIAKAN KK (2015). Defining the three cell lineages of the human blastocyst by single-cell RNA-seq. Development 142 3613-3613.

BLIJ S, FRUM T, AKYOL A, FEARON E, RALSTON A (2012). Maternal Cdx2 is dispensable for mouse development. Development 139: 3969-3972.

BURTON A, MULLER J, TU S, PADILLA-LONGORIA P, GUCCIONE E, TORRESPADILLAME (2013). Single-Cell Profiling of Epigenetic Modifiers Identifies PRDM14 as an Inducer of Cell Fate in the Mammalian Embryo. Cell Rep 5: 687-701.

CAPALBO A, UBALDI FM, CIMADOMO D, NOLI L, KHALAF Y, FARCOMENI A, ILIC $D, R I E N Z I$ L (2016). MicroRNAs in spent blastocyst culture medium are derived from trophectoderm cells and can be explored for human embryo reproductive competence assessment. Fertil Steril 105: 225-235e3.

CHAI N, PATEL Y, JACOBSON K, MCMAHON J, MCMAHON A, RAPPOLEE DA (1998). FGF is an essential regulator of the fifth cell division in preimplantation mouse embryos. Dev Biol 198: 105-115.

CHAZAUD C, YAMANAKAY (2016). Lineage specification in the early mouse embryo. Development 143: 1063-1074. CLAYTON L, HALL A, JOHNSON MH (1999). A role for Rho-like GTPases in the polarisation of mouse eight-cell blastomeres. Dev Biol 205: 322-331.

COCKBURN K, BIECHELE S, GARNER J, ROSSANT J (2013). The hippo pathway member nf2 is required for inner cell mass specification. Curr Biol23: 1195-1201.

COCKBURN K, ROSSANT J (2010). Making the blastocyst: lessons from the mouse. J Clin Invest 120: 995-1003.

COPPAJ (1979). Interaction between inner cell mass and trophectoderm of the mouse blastocyst: A study of cellular proliferation. J Embryol Exp Morphol. 48: 109-125.

DARD N, LOUVET-VALLÉE S, MARO B (2009). Orientation of mitotic spindles during the 8- to 16cell stage transition in mouse embryos. PLoS One 4: 6-13.

DENG Q, RAMSKOLD D, REINIUS B, SANDBERG R (2014). Single-Cell RNA-Seq Reveals Dynamic, Random Monoallelic Gene Expression in Mammalian Cells. Science 343: 193-196.

DIETRICH J-E, HIIRAGIT (2007). Stochastic patterning in the mouse pre-implantation embryo. Development 134: 4219-4231.

ECKERT JJ, MCCALLUM A, MEARS A, RUMSBY MG, CAMERON IT, FLEMING TP (2004). Specific PKC isoforms regulate blastocoel formation during mouse preimplantation development. Dev Biol 274: 384-401.

ERLEBACHER A, PRICE KA, GLIMCHER LH (2004). Maintenance of mouse trophoblast stem cell proliferation by TGF- $\beta$ /activin. Dev Biol 275: 158-169.

FELDMAN B, POUEYMIROU W, PAPAIOANNOU VE, DECHIARA TM, GOLDFARB M (1995). Requirement of FGF-4 for postimplantation mouse development. Sci- 
ence 267: 246-249.

FIERRO-GONZÁLEZ JC, WHITE MD, SILVA JC, PLACHTA N (2013). Cadherindependent filopodia control preimplantation embryo compaction. Nat Cell Biol 15: 1424-1433.

FLEMING TP, JOHNSON MH (1988). From Egg to Epithelium. Annu Rev Cell Biol 4: 459-485.

FOGARTY NME, MCCARTHY A, SNIJDERS KE, POWELL BE, KUBIKOVA N, BLAKELEY P, LEA R, ELDER K, WAMAITHA SE, KIM D, MACIULYTE V, KLEINJUNG J, KIM JS, WELLS D, VALLIER L, BERTERO A, TURNER JMA, NIAKAN KK (2017). Genome editing reveals a role for OCT4 in human embryogenesis. Nature 550: 67-73.

FRAGOULI E, SPATH K, ALFARAWATIS, KAPER F, CRAIG A, MICHEL CE, KOKOCINSKIF, COHEN J, MUNNE S, WELLSD (2015). Altered Levels of Mitochondrial DNA Are Associated with Female Age, Aneuploidy, and Provide an Independent Measure of Embryonic Implantation Potential. Obstet Gynecol Surv11: e1005241.

FRAGOULIE, WELLSD (2015). Mitochondrial DNAAssessment to Determine Oocyte and Embryo Viability. Semin Reprod Med 33: 401-409.

FU Z, WANG B, WANG S, WU W, WANG Q, CHEN Y, KONG S, LU J, TANG Z, RAN $\mathrm{H}$, et al., (2014). Integral Proteomic Analysis of Blastocysts Reveals Key Molecular Machinery Governing Embryonic Diapause and Reactivation for Implantation in Mice1. Biol Reprod 90: 1-11.

FUJIMORI T, KUROTAKI Y, KOMATSU K, NABESHIMA YI (2009). Morphologica organization of the mouse preimplantation embryo. Reprod Sci 16: 171-177.

GAMAGE TKJB, CHAMLEY LW, JAMES JL (2016). Stem cell insights into human trophoblast lineage differentiation. Hum Reprod Update 23: 77-103.

GENBACEV O, DONNE M, KAPIDZIC M, GORMLEY M, LAMB J, GILMORE J, LAROCQUE N, GOLDFIEN G, ZDRAVKOVIC T, MCMASTER MT, FISHER SJ (2011). Establishment of human trophoblast progenitor cell lines from the chorion. Stem Cells 29: 1427-36. doi: 10.1002/stem.686.

GASSER RF (1975). Atlas of Human Embryos. Harper and Row, New York. pp. 7-13

GOOLAM M, SCIALDONE A, GRAHAM SJL, MACAULAY IC, JEDRUSIK A, HUPALOWSKA A, VOET T, MARIONI JC, ZERNICKA-GOETZ M (2016). Heterogeneity in Oct4 and Sox2 Targets Biases Cell Fate in 4-Cell Mouse Embryos. Cell 165: 61-74.

GRABAREK JB, ZYZYNSKA K, SAIZ N, PILISZEK A, FRANKENBERG S, NICHOLS J, HADJANTONAKIS A, PLUSA B (2012). Differential plasticity of epiblast and primitive endoderm precursors within the ICM of the early mouse embryo. Development 139: 129-39. doi: 10.1242/dev.067702.

GRAHAM SJL, WICHER KB, JEDRUSIK A, GUO G, HERATH W, ROBSON P, ZERNICKAGOETZ M (2014). BMP signalling regulates the pre-implantation development of extra-embryonic cell lineages in the mouse embryo. Nat Commun 5: 1-11.

GRATI FR, MALVESTITI F, FERREIRA JCPB, BAJAJ K, GAETANI E, AGRATI C, GRIMI B, DULCETTI F, RUGGERI AM, DE TOFFOL S, MAGGI F, WAPNER R, GROSS S, SIMONI G (2014). Fetoplacental mosaicism: Potential implications for false-positive and false-negative noninvasive prenatal screening results. Genet Med 16: 620-624.

GRECO E, MINASI MG (2015). Healthy Babies after Intrauterine Transfer of Mosaic Aneuploid Blastocysts. N Engl J Med 373: 2089-2090.

GUO G, HUSS M, TONG GQ, WANG C, LI SUN L, CLARKE ND, ROBSON P (2010). Resolution of Cell Fate Decisions Revealed by Single-Cell Gene Expression Analysis from Zygote to Blastocyst. Dev Cell 18: 675-685.

HALDER G, DUPONT S, PICCOLO S (2012). Transduction of mechanical and cytoskeletal cues by YAP and TAZ. Nat Rev Mol Cell Biol 13: 591-600.

HANDYSIDE AH (1978). Time of commitment of inside cells isolated from preimplantation mouse embryos. J Embryol Exp Morph 45: 37-53.

HANNIBALRL, BAKERJC (2016). Selective Amplification of the Genome Surrounding Key Placental Genes in Trophoblast Giant Cells. Curr Biol 26: 230-236.

HIRATE Y, HIRAHARA S, INOUE KI, SUZUKI A, ALARCON VB, AKIMOTO K, HIRAI T, HARA T, ADACHI M, CHIDAK, OHNO S, MARIKAWA Y, NAKAO K, SHIMONO A, SASAKI H (2013). Polarity-dependent distribution of angiomotin localizes hippo signaling in preimplantation embryos. Curr Biol 23: 1181-1194.

HOGAN B, TILLY R (1978). In vitro development of inner cell masses isolated immunosurgically from mouse blastocysts. II. Inner cell masses from 3.5- to 4.0-day p.c. blastocysts. J Embryol Exp Morphol 45: 107-121.

HOUGHTON FD (2006). Energy metabolism of the inner cell mass and trophectoderm of the mouse blastocyst. Differentiation 74: 11-18.

HUANG J, YAN L, LU S, ZHAO N, QIAO J (2017). Re-analysis of aneuploidy blastocysts with an inner cell mass and different regional trophectoderm cells. J Assist Reprod Genet 34: 487-493.

JOHNSON MH, MARO B (1985). A dissection of the mechanisms generating and stabilizing polarity in mouse 8- and 16-cell blastomeres: the role of cytoskeletal elements. J Embryol Exp Morphol 90: 311-334.

JOHNSON MH, ZIOMEK CA(1981). Induction of polarity in mouse 8-cell blastomeres: Specificity, geometry, and stability. J Cell Biol 91: 303-308.

JOHNSON MH, ZIOMEK CA (1981). The foundation of two distinct cell lineages within the mouse morula. Cell 24: 71-80.

JURISICOVA A, ANTENOSM, KAPASIK, MERIANOJ, CASPERRF (1999). Variability in the expression of trophectodermal markers $\beta$-human chorionic gonadotrophin, human leukocyte antigen-G and pregnancy specific $\beta-1$ glycoprotein by the human blastocyst. Hum Reprod 14: 1852-1858.

JURISICOVA A, CASPER RF, MACLUSKY NJ, MILLS GB, LIBRACH CL (1996). HLA-G expression during preimplantation human embryo development. Proc Natl Acad Sci USA 93: 161-165.

KONO K, TAMASHIRO DAA, ALARCON VB (2014). Inhibition of RHO-ROCK signaling enhances ICM and suppresses TE characteristics through activation of Hippo signaling in the mouse blastocyst. Dev Biol 394: 142-155.

KOROTKEVICH E, NIWAYAMA R, COURTOIS A, FRIESE S, BERGER N, BUCHHOLZ F, HIIRAGI T (2017). The Apical Domain Is Required and Sufficient for the First Lineage Segregation in the Mouse Embryo. Dev Cell 40: 235-247.e7.

KUIJK EW, VAN TOL LTA, VAN DE VELDE H, WUBBOLTS R, WELLING M, GEIJSEN N, ROELEN BAJ (2012). The roles of FGF and MAP kinase signaling in the segregation of the epiblast and hypoblast cell lineages in bovine and human embryos. Development 139: 871-882.

KUNATH T, YAMANAKA Y, DETMAR J, MACPHEE D, CANIGGIA I, ROSSANT J, JURISICOVA A (2014). Developmental differences in the expression of FGF receptors between human and mouse embryos. Placenta 35: 1079-1088.

KUSHNIR VA, DARMON SK, BARADDH, GLEICHERN (2018). Degree of mosaicism in trophectoderm does not predict pregnancy potential: A corrected analysis of pregnancy outcomes following transfer of mosaic embryos. Reprod Biol Endocrinol 16(1):6. doi: 10.1186/s12958-018-0322-5

LEAVEY K, BENTON SJ, GRYNSPAN D, KINGDOM JC, BAINBRIDGE SA, COX BJ (2016). Unsupervised Placental Gene Expression Profiling Identifies Clinically Relevant Subclasses of Human Preeclampsia. Hypertension 68: 137-147.

LEE CQE, GARDNERL, TURCO M, ZHAON, MURRAY MJ, COLEMAN N, ROSSANT J, HEMBERGER M, MOFFETT A (2016). What Is Trophoblast? A Combination of Criteria Define Human First-Trimester Trophoblast. Stem Cell Reports 6: 257-272.

LEUNG CY, ZERNICKA-GOETZ M (2013). Angiomotin prevents pluripotent lineage differentiation in mouse embryos via Hippo pathway-dependent and-independent mechanisms. Nat Commun 4: 1-11.

LI L, SCHUST DJ (2015). Isolation, purification and in vitro differentiation of cytotrophoblast cells from human term placenta. Reprod Biol Endocrinol 13: 1-9.

LI Y, XU J, ZHOU CQ, ZHANG CL, ZHUANG GL (2016). Nonprofessional phagocytosis in trophectoderm cells of human preimplantation blastocysts. Syst Bio Reprod Med 62: 243-248.

LORTHONGPANICH C, DORIS TPY, LIMVIPHUVADH V, KNOWLES BB, SOLTER D (2012). Developmental fate and lineage commitment of singled mouse blastomeres. Development 139: 3722-3731.

MA GT, SOLOVEVA V, TZENG SJ, LOWE LA, PFENDLER KC, IANNACCONE PM, KUEHN MR, LINZER DIH (2001). Nodal regulates trophoblast differentiation and placental development. Dev Biol 236: 124-135.

MAÎTRE JL, BERTHOUMIEUXH, KRENSSFG, SALBREUXG, JÜLICHERF, PALUCH E, HEISENBERG CP (2012). Adhesion functions in cell sorting by mechanically coupling the cortices of adhering cells. Science 338: 253-256.

MAîTRE JL, NIWAYAMA R, TURLIER H, NEDELEC F, HIIRAGI T (2015). Pulsatile cell-autonomous contractility drives compaction in the mouse embryo. Nat Cell Biol 17: 849-855.

MAÎTRE JL, TURLIER H, ILLUKKUMBURA R, EISMANN B, NIWAYAMA R, NÉDÉLEC F, HIIRAGI T (2016). Asymmetric division of contractile domains couples cell positioning and fate specification. Nature 536: 344-348.

MITSUI K, TOKUZAWA Y, ITOH H, SEGAWA K, MURAKAMI M, TAKAHASHI K 
MARUYAMA M, MAEDA M, YAMANAKA S (2003). The homeoprotein nanog is required for maintenance of pluripotency in mouse epiblast and ES cells. Cell 113: $631-642$.

MORRIS SA, TEO RTY, LI H, ROBSON P, GLOVER DM, ZERNICKA-GOETZ M (2010). Origin and formation of the first two distinct cell types of the inner cell mass in the mouse embryo. Proc Natl Acad Sci USA 107: 6364-6369.

MUNNÉ S, BLAZEK J, LARGE M, MARTINEZ-ORTIZ PA, NISSON H, LIU E, TAROZZI N, BORINI A, BECKER A, ZHANG J, MAXWELL S, GRIFO J, BABARIYA D, WELLS D, FRAGOULI E (2017). Detailed investigation into the cytogenetic constitution and pregnancy outcome of replacing mosaic blastocysts detected with the use of high-resolution next-generation sequencing. Fertil Steril 108:62-71.e8.

NAKAMURAT, YABUTAY, OKAMOTOI, ARAMAKIS, YOKOBAYASHIS, KURIMOTO K, SEKIGUCHI K, NAKAGAWA M, YAMAMOTO T, SAITOU M (2015). SC3-seq: A method for highly parallel and quantitative measurement of single-cell gene expression. Nucleic Acids Res 43:e60. doi: 10.1093/nar/gkv134.

NIAKAN KK, EGGAN K (2013). Analysis of human embryos from zygote to blastocyst reveals distinct gene expression patterns relative to the mouse. Dev Biol375:54-64.

NICHOLS J, SILVA J, ROODE M, SMITH A (2009). Suppression of Erk signalling promotes ground state pluripotency in the mouse embryo. Development 136: 3215-3222.

NICHOLS J, ZEVNIK B, ANASTASSIADIS K, NIWA H, KLEWE-NEBENIUS D, CHAMBERS I, SCHOLER H, SMITH A (1998). Formation of pluripotent stem cells in the mammalian embryo dependes on the POU transcription factor Oct4. Cell 95: 379-391.

NISHIOKA N, YAMAMOTO S, KIYONARI H, SATO H, SAWADA A, OTA M, NAKAO $\mathrm{K}$, SASAKI H (2008). Tead4 is required for specification of trophectoderm in preimplantation mouse embryos. Mech Dev 125: 270-283.

NOSI U, LANNER F, HUANG T, COX B (2017). Overexpression of Trophoblast Stem Cell-Enriched MicroRNAs Promotes Trophoblast Fate in Embryonic Stem Cells. Cell Rep 19: 1101-1109.

OHSUGI M, OHSAWA T, YAMAMURA H (1993). Involvement of protein kinase C in nuclear migration during compaction and the mechanism of the migration: Analyses in two-cell mouse embryos. Dev Biol 156: 146-154.

OKAE H, TOH H, SATO T, HIURA H, TAKAHASHI S, SHIRANE K, KABAYAMA Y, SUYAMAM, SASAKI H, ARIMA T (2018). Derivation of Human Trophoblast Stem Cells. Cell Stem Cell 22: 50-63.e6.

DE PAEPE C, CAUFFMAN G, VERLOESA, STERCKX J, DEVROEY P, TOURNAYE H, LIEBAERS I, VAN DE VELDE H (2013). Human trophectoderm cells are not yet committed. Hum Reprod 28: 740-749.

PALMIERI SL, PETER W, HESS H, SCHÖLER HR (1994). Oct-4 transcription factor is differentially expressed in the mouse embryo during establishment of the firsttwo extraembryonic cell lineages involved in implantation. Dev Biol 166: 259-267.

PETROPOULOS S, EDSGÄRD D, REINIUS B, DENG Q, PANULASP, CODELUPPI S, PLAZA REYES A, LINNARSSON S, SANDBERG R, LANNER F (2016). Single-Cell RNA-Seq Reveals Lineage and X Chromosome Dynamics in Human Preimplantation Embryos. Cell 165: 1012-1026.

PICCOLOMINI MM, NICOLIELO M, BONETTI TCS, MOTTA ELA, SERAFINI PC, ALEGRETTIJR (2016). Does slow embryo development predict a high aneuploidy rate on trophectoderm biopsy? Reprod Biomed Online 33: 398-403.

PICKERING SJ, MARO B, JOHNSON MH, SKEPPER JN (1988). The influence of cell contact on the division of mouse 8-cell blastomeres. Development 103: 353-63.

PLACHTA N, BOLLENBACH T, PEASE S, FRASER SE, PANTAZIS P (2011). Oct4 kinetics predict cell lineage patterning in the early mammalian embryo. Nat Cell Biol 13: 117-123

POSFAI E, PETROPOULOS S, DE BARROS FRO, SCHELL JP, JURISICA I, SANDBERG R, LANNER F, ROSSANTJ (2017). Position- and hippo signaling-dependent plasticity during lineage segregation in the early mouse embryo. Elife 6: 1-24.

QIN H, BLASCHKE K, WEI G, OHI Y, BLOUIN L, QI Z, YU J, YEH RF, HEBROK M, RAMALHOSANTOSM (2012). Transcriptional analysis of pluripotency reveals the hippo pathway as a barrier to reprogramming. Hum Mol Genet 21: 2054-2067.

RALSTON A, COX BJ, NISHIOKA N, SASAKI H, CHEA E, RUGG-GUNN P, GUO G, ROBSONP, DRAPER JS, ROSSANTJ (2010). Gata3 regulates trophoblast development downstream of Tead4 and in parallel to Cdx2. Development 137:395-403.

RALSTON A, ROSSANT J (2008). Cdx2 acts downstream of cell polarization to cell-autonomously promote trophectoderm fate in the early mouse embryo. Dev Biol 313: 614-629.
RASSOULZADEGAN M, ROSEN BS, GILLOT I, CUZIN F (2000). Phagocytosis reveals a reversible differentiated state early in the development of the mouse embryo. EMBO J 19: 3295-3303.

RIVRON NC, FRIAS-ALDEGUER J, VRIJ EJ, BOISSET JC, KORVING J, VIVIÉ J, TRUCKENMÜLLER RK, VAN OUDENAARDEN A, VAN BLITTERSWIJK CA, GEIJSEN N (2018). Blastocyst-like structures generated solely from stem cells. Nature 557: 106-111.

ROODE M, BLAIR K, SNELL P, ELDER K, MARCHANT S, SMITH A, NICHOLS J (2012). Human hypoblast formation is not dependent on FGF signalling. Dev Biol 361: 358-363.

ROSSANT J, LIS WT (1979). Potential of isolated mouse inner cell masses to form trophectoderm derivatives in vivo. Dev Biol 70: 255-261.

ROSSANT J, VIJH KM (1980). Ability of outside cells from preimplantation mouse embryos to form inner cell mass derivatives. Dev Biol 76: 475-482.

SAMARAGE CR, WHITE MD, ÁLVAREZ YD, FIERRO-GONZÁLEZ JC, HENON Y, JESUDASON EC, BISSIERE S, FOURASA, PLACHTAN (2015). Cortical Tension Allocates the First Inner Cells of the Mammalian Embryo. Dev Cell 34: 435-447.

SCREEN M, DEAN W, CROSS JC, HEMBERGER M (2008). Cathepsin proteases have distinct roles in trophoblast function and vascular remodelling. Development 135: 3311-3320.

SHER N, VON STETINA JR, BELL GW, MATSUURA S, RAVID K, ORR-WEAVERTL (2013). Fundamental differences in endoreplication in mammals and Drosophila revealed by analysis of endocycling and endomitotic cells. Proc Natl Acad Sci USA 110: 9368-9373.

SOBEL JS (1983). Cell-cell contact modulation of myosin organization in the early mouse embryo. Dev Biol 100: 207-213.

SONCIN F, NATALE D, PARAST MM, DIEGO CS, JOLLA L, JOLLA L, DIEGO CS, JOLLAL (2014). Signaling pathways in mouse and human trophoblast differentiation: a comparative review. Cell Mol Life Sci. 72: 1291-1302.

SPINDLE A (1978). Trophoblast regeneration by inner cell masses isolated from cultured mouse embryos. J Exp Zool 203: 483-489.

SPINELLA F, FIORENTINO F, BIRICIK A, BONO S, RUBERTI A, COTRONEO E, BALDI M, CURSIO E, MINASI MG, GRECO E (2018). Extent of chromosomal mosaicism influences the clinical outcome of in vitro fertilization treatments. Fertil Steril 109: 77-83.

STEPHENSON RO, YAMANAKA Y, ROSSANT J (2010). Disorganized epithelial polarity and excess trophectoderm cell fate in preimplantation embryos lacking E-cadherin. Development 137: 3383-3391.

STIRPARO GG, BOROVIAK T, GUO G, NICHOLS J, SMITH A, BERTONE P (2018). Integrated analysis of single-cell embryo data yields a unified transcriptome signature for the human preimplantation epiblast. Development 145: dev169672.

STRNAD P, GUNTHER S, REICHMANN J, KRZIC U, BALAZS B, DE MEDEIROS G, NORLIN N, HIIRAGI T, HUFNAGEL L, ELLENBERG J (2016). Inverted light-sheet microscope for imaging mouse pre-implantation development. Nat Methods 13: 139-142.

STRUMPF D (2005). Cdx2 is required for correct cell fate specification and differentiation of trophectoderm in the mouse blastocyst. Development 132: 2093-2102.

SUN X, ST. JOHN JC (2016). The role of the mtDNA set point in differentiation, development and tumorigenesis. Biochem J 473: 2955-2971.

SURANI M a, BARTON SC (1977). Trophoblastic vesicles of preimplantation blastocysts can enter into quiescence in the absence of inner cell mass. J Embryol Exp Morphol 39: 273-277.

SUWIŃSKAA, CZOŁOWSKAR, OZDZEŃSKIW, TARKOWSKIAK(2008). Blastomeres of the mouse embryo lose totipotency after the fifth cleavage division: Expression of Cdx2 and Oct4 and developmental potential of inner and outer blastomeres of 16- and 32-cell embryos. Dev Biol 322: 133-144.

TABIASCO J, D'HAUTERIVE SP, THONON F, PARINAUD J, LÉANDRI R, FOIDART JM, CHAOUAT G, MUNAUT C, LOMBROSO R, SELVA J, BERGËRE M, HAMMOUD I, KOZMA N, AGUERRE-GIRR M, SWALES AKE, SARGENT IL, LE BOUTEILLER P, LÉDÉE N (2009). Soluble HLA-G in IVF/ICSI embryo culture supernatants does not always predict implantation success: A multicentre study. Reprod Biomed Online 18: 374-381.

TANAKATS, KUNATHT, KIMBER WL, JARADATSA, STAGG CA, USUDAM, YOKOTA T, NIWA H, ROSSANT J, KO MSH (2002). Gene Expression Profiling of EmbryoDerived Stem Cells Reveals Candidate Genes Associated With Pluripotency and Lineage Specificity. Genome Res 12: 1921-1928. 
TARKOWSKI AK, SUWIŃSKAA, CZOLOWSKA R, OZDZEZSKI W (2010). Individual blastomeres of 16- and 32-cell mouse embryos are able to develop into foetuses and mice. Dev Biol 348: 190-198.

TARKOWSKI AK, WRÓBLEWSKA J (1967). Development of blastomeres of mouse eggs isolated at the 4- and 8-cell stage. J Embryol Exp Morphol 18: 155-180.

TAYLOR TH, GRIFFIN DK, KATZ SL, CRAIN JL, JOHNSON L, GITLIN S (2016). Technique to "Map" Chromosomal Mosaicism at the Blastocyst Stage. Cytogenet Genome Res 149: 262-266.

TORRES-PADILLA ME, PARFITT DE, KOUZARIDES T, ZERNICKA-GOETZ M (2007). Histone arginine methylation regulates pluripotency in the early mouse embryo. Nature 445: 214-218.

VARMUZA S, RASHMI KOTHARY VP, ROSSANT J (1988). Polytene chromosomes in mouse trophoblast giant cells. Development 102: 127-134.

VINOT S, LE T, OHNO S, PAWSON T, MARO B, LOUVET-VALLÉE S (2005). Asymmetric distribution of PAR proteins in the mouse embryo begins at the 8-cell stage during compaction. Dev Biol 282: 307-319.

DE VRIES WN, EVSIKOV A V., HAAC BE, FANCHER KS, HOLBROOKAE, KEMLER R, SOLTER D, KNOWLES BB (2004). Maternal -catenin and E-cadherin in mouse development. Development 131: 4435-4445.

WATANABE T, BIGGINS JS, TANNAN NB, SRINIVAS S (2014). Limited predictive value of blastomere angle of division in trophectoderm and inner cell mass specification. Development 141: 2279-2288.

WATSONAJ, NATALE DR, BARCROFT LC (2004). Molecular regulation of blastocyst formation. Anim Reprod Sci 82-83: 583-592.

WEIER JF, WEIER HUG, JUNG CJ, GORMLEY M, ZHOU Y, CHU LW, GENBACEV O, WRIGHTAA, FISHERSJ (2005). Human cytotrophoblasts acquire aneuploidies as they differentiate to an invasive phenotype. Dev Biol 279: 420-432.

WHITE MD, ANGIOLINI JF, ALVAREZ YD, BISSIERE S, LEVI V, PLACHTAN (2016). Long-Lived Binding of Sox2 toDNAPredicts Cell Fate in the Four-Cell Mouse Embryo. Cell 165: 75-87.

WICKLOW E, BLIJ S, FRUM T, HIRATE Y, LANG RA, SASAKI H, RALSTON A (2014). HIPPO Pathway Members Restrict SOX2 to the Inner Cell Mass Where It Promotes ICM Fates in the Mouse Blastocyst. PLoS Genet 10 e1004618. doi: 10.1371/journal.pgen.1004618
WIGGER M, KISIELEWSKA K, FILIMONOW K, PLUSA B, MALESZEWSKI M, SUWIŃSKA A (2017). Plasticity of the inner cell mass in mouse blastocyst is restricted by the activity of FGF/MAPK pathway. Sci Rep 7: 1-13.

WINKEL GK, FERGUSON JE, TAKEICHI M, NUCCITELLI R (1990). Activation of Protein Kinase C Triggers Premature Compaction in the Four-Cell Stage Mouse Emrbyo. Dev Biol. 138: 1-15.

YAGI R, KOHN MJ, KARAVANOVA I, KANEKO KJ, VULLHORST D, DEPAMPHILIS ML, BUONANNO A (2007). Transcription factor TEAD4 specifies the trophectoderm lineage at the beginning of mammalian development. Development 134 3827-3836.

YAMANAKA Y, LANNER F, ROSSANT J (2010). FGF signal-dependent segregation of primitive endoderm and epiblast in the mouse blastocyst. Development 137: 715-724.

YAN L, YANG M, GUO H, YANG L, WU J, LI R, LIU P, LIAN Y, ZHENG X, YAN J, HUANG J, LI M, WU X, WEN L, LAO K, LI R, QIAO J, TANG F (2013). Single-cell RNA-Seq profiling of human preimplantation embryos and embryonic stem cells. Nat Struct Mol Biol 20: 1131-1139.

YU C, JI SY, DANG YJ, SHA QQ, YUAN YF, ZHOU JJ, YAN LY, QIAO J, TANG F, FAN HY (2016). Oocyte-expressed yes-associated protein is a key activator of the early zygotic genome in mouse. Cell Res 26: 275-287.

ZDRAVKOVIC T, NAZOR KL, LAROCQUE N, GORMLEY M, DONNE M, HUNKAPILLAR N, GIRITHARAN G, BERNSTEIN HS, WEI G, HEBROK M, ZENG X, GENBACEV O, MATTIS A, MCMASTER MT (2015). Human stem cells from single blastomeres reveal pathways of embryonic or trophoblast fate specification. Development 142: 4010-4025.

ZENKER J, WHITE MD, GASNIER M, ALVAREZ YD, LIM HYG, BISSIERE S, BIRO M, PLACHTA N (2018). Expanding Actin Rings Zipper the Mouse Embryo for Blastocyst Formation. Cell 173: 776-791.e17.

ZHU M, LEUNG CY, SHAHBAZI MN, ZERNICKA-GOETZ M (2017). Actomyosin polarisation through PLC-PKC triggers symmetry breaking of the mouse embryo. Nat Commun 8(1):921. doi: 10.1038/s41467-017-00977-8.

ZIOMEK CA, JOHNSON MH, HANDYSIDE AH (1982). The developmental potential of mouse 16 cell blastomeres. J Exp Zool 221: 345-355. 


\section{Further Related Reading, published previously in the Int. J. Dev. Biol.}

Planar polarity of the extraembryonic epithelia in the preimplantation porcine conceptus Jacques-Edmond Flechon

Int. J. Dev. Biol. (2017) 61: 505-517

https://doi.org/10.1387/ijdb.170044jf

DNA methylation and its role in the trophoblast cell lineage

Satoshi Tanaka, Momo O. Nakanishi and Kunio Shiota

Int. J. Dev. Biol. (2014) 58: 231-238

https://doi.org/10.1387/ijdb.140053st

The evolution of embryo implantation

Michael R. McGowen, Offer Erez, Roberto Romero and Derek E. Wildman

Int. J. Dev. Biol. (2014) 58: 155-161

https://doi.org/10.1387/ijdb.140020dw

The effect of superovulation on the contributions of individual blastomeres from 2-cell stage CF1 mouse embryos to the blastocyst

Mika Katayama and R. Michael Roberts

Int. J. Dev. Biol. (2010) 54: 675-681

https://doi.org/10.1387/ijdb.092942mk

\section{Split immunological tolerance to trophoblast}

Amanda de Mestre, Leela Noronha, Bettina Wagner and Douglas F. Antczak

Int. J. Dev. Biol. (2010) 54: 445-455

https://doi.org/10.1387/ijdb.082795ad

Development and function of trophoblast giant cells in the rodent placenta Dong $\mathrm{Hu}$ and James C. Cross

Int. J. Dev. Biol. (2010) 54: 341-354

https://doi.org/10.1387/ijdb.082768dh

Developmental cell biology of human villous trophoblast: current research problems John D. Aplin

Int. J. Dev. Biol. (2010) 54: 323-329

https://doi.org/10.1387/ijdb.082759ja
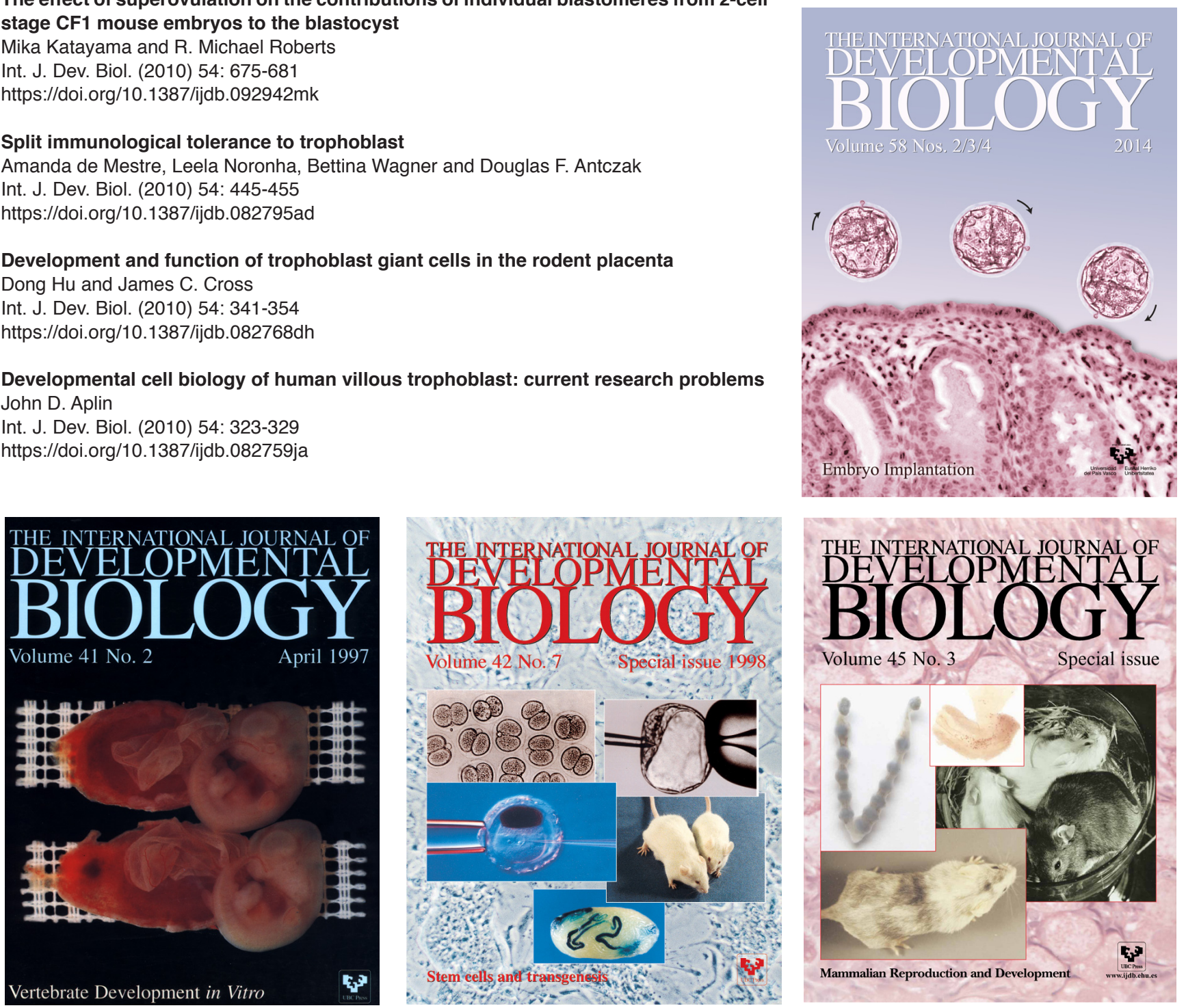